\title{
From Black Pain to Rhodes Must Fall: A Rejectionist Perspective
}

\author{
Rashedur Chowdhury ${ }^{1}$
}

Received: 4 February 2018 / Accepted: 4 November 2019 / Published online: 26 November 2019

(c) The Author(s) 2019

\begin{abstract}
Based on my study of the Rhodes Must Fall movement, I develop a rejectionist perspective by identifying the understanding and mobilization of epistemic disobedience as the core premise of such a perspective. Embedded in this contextual perspective, epistemic disobedience refers to the decolonization of the self and a fight against colonial legacies. I argue that, rather than viewing a rejectionist perspective as a threat, it should be integrated into the moral learning of contemporary institutions and businesses. This approach is important in ensuring colonial legacies and biases do not create further racism or unequal situations for marginalized groups. The implication for critical management studies is that scholars from this camp should be more sensitive to issues of black consciousness and implement an authentic pragmatic ideal to promote black culture and historiographies in universities and curricula. It also highlights a need for the field of business ethics to apply more sensitive theory of marginalized stakeholders in order to prevent any escalation of violence by multinational corporations in the name of shareholder value creation and profit-maximization.
\end{abstract}

Keywords Black scholarship · Ethics $\cdot$ Justice $\cdot$ Inequality $\cdot$ Postcolonial theory $\cdot$ Stakeholder theory $\cdot$ Pedagogy $\cdot$ Decolonization · Critical management studies (CMS) - Social movement · Curriculum · Resistance

\section{Introduction}

Over the last few centuries, many Western countries benefited from colonialism and racism (Miller 1988; Thornton 1998), using race as a vehicle to transport slaves into their own lands, and institutionalizing slavery to secure wealth and happiness for their own people (Beckert 2014). By grounding racism into their core belief system, these countries not only colonized Africa and Asia to exploit material and human capital but also normalized racial oppression in all aspects of life. Consequently, although many of the colonized countries eventually achieved independence, they are still subject to colonial legacies (Guha 2002; Hountondji 1992). One of the long-lasting negative outcomes of such legacy is that it has transformed into a neoliberal Westernized-style capitalist system dominated by white populations (Hahn 2005; Harvey 2005) and has thus created safe passage for Western multinational corporations (MNCs) to dominate the everyday lives of marginalized groups of color (Onimode

Rashedur Chowdhury

R.R.Chowdhury@soton.ac.uk

1 Southampton Business School, University of Southampton, 12 University Rd, Highfield, Southampton SO17 1BJ, UK
1978; Udofia 1984). Such marginalized groups are dominated by powerful actors such as government agencies, MNCs, elite non-governmental organizations (NGOs), and Western aid agencies and institutions (Chowdhury 2019). Examples of marginalized groups include powerless communities, economically poor labor forces, religious minorities, and groups that are subject to racial biases and discrimination by being locked into white dominated neoliberalist mechanisms.

Based on the above, in this article, I do not seek an explanation for how MNCs dominate so-called developing countries. [See, for example, Khan et al. (2007, 2010), Maher (2018), Masika (2017) and Varman and Al-Amoudi (2016) who are concerned about such issues.] Instead, I focus on how racism is deeply embedded in colonial legacies that influence MNCs as dominant Westernized institutions that control marginalized groups (c.f., Chowdhury 2019; Girei 2017). Without this focus, it is difficult to conceptualize many ethical dilemmas that MNCs produce while continuing to normalize them in postcolonial countries (see, $\mathrm{Pal} 2016$ ).

MNCs play a crucial part in generating ethical dilemmas as they rely on exploitative ideologies such as economic efficiencies and labor exploitation for higher profit margins (Cooke 1999, 2003). These ideologies were developed over 
centuries (Rosenthal 2018) and research on how affected parties react to such ideologies remains scarce. This limitation can be addressed by engaging with South Africa's Rhodes Must Fall (RMF) movement. This not only provides a unique opportunity to explore more contemporary issues of colonial legacy that prevail through structural and racist means but also to examine exploitative business interests rooted within racism which helped nineteenth-century British colonialist Cecil Rhodes to become a perceived figure of status. Rhodes was a British mining magnate and a politician in southern Africa who served as Prime Minister of the Cape Colony from 1890 to 1896 and who lends his name to South Africa's Rhodes University. He also funded the Rhodes scholarship for international students to study at the UK's Oxford University. The RMF movement was triggered at the University of Cape Town (UCT), South Africa, on 9 March 2015 (Kamanzi 2015) to resist the violent legacy of Rhodes. It started when Chumani Maxwele, a student from UCT, threw a bucket of human feces onto a bronze statue of Rhodes (Harding 2015). Under enormous student and public pressure, on 27 March 2015, the UCT's senate voted in favor of removing the Rhodes statue, and this took place on 9 April (The Oppidan Press, n.d.).

I chose to study the RMF movement for two reasons. First, it is imperative to examine deep moral concerns over why former colonial structures (e.g., universities) continue to preserve and embed symbols and practices of colonialism and racism (e.g., by implementing 'whiteness' through ideologies and curricula), thereby adversely affecting marginalized groups such as black students in South Africa. Second, it is also important to understand how black students interpret their consciousness and achieve their power through their pursuit of freedom and justice.

My central argument is that the idea of removing the Rhodes statue was born from a 'rejectionist perspective,' which I define as a stance that fights against institutions and knowledge that have colonial, imperialist, and racist foundations. In my conceptualization a rejectionist perspective has two fundamental elements: (1) An understanding of epistemic disobedience and (2) the mobilization of epistemic disobedience to decolonize imperialist institutions/structures. Epistemic disobedience can be defined as the process of "decolonializing and de-colonial knowledges, necessary steps for imagining and building democratic, just, and nonimperial/ colonial societies" (Mignolo 2009, p. 1). Based on an indepth interview with an activist from the RMF movement, I highlight why it is important to conceptualize the rejectionist perspective for scholarly debates, with related moral implications for societies, institutions and businesses where colonial legacies and issues of race still permeate everyday life. By doing so, I emphasize that, despite such a perspective, marginalized groups must not be treated as disenfranchised or reactionary, as they can use their collective consciousness to fight injustice. They do not simply rely on reactionary practices to challenge a system (Mansbridge and Morris 2001; Morris 2000) that tends to treat them as a subject of research (Spivak 1990). Henceforth, both critical management and business ethics scholars must advance moral learning of the rejectionist perspective because it creates new possibilities for academic debate about how marginalized groups can be perceived, interacted with and studied, particularly given the context of the Westernized, dominant institutionalism or colonial legacies that they encounter and are subjected to on a daily basis.

This article is organized as follows: I start with literature that has relevance to the development of the rejectionist perspective. By doing so, I not only interpret the RMF movement but also enrich our knowledge regarding neocolonialism, criticality, morality and ethics and their implications for the MNCs and educational institutions that still enable racial oppressions. Second, I highlight the context of the RMF movement and the methodology (including my positionality to study this movement) that I employed to conceptualize the rejectionist perspective. Third, I present my findings based on an interview with a RMF activist, followed by discussion and conclusion.

\section{Background Literature: Locating the Relevance of the Rejectionist Perspective}

The rejectionist perspective can fall into two relevant camps of study: (1) Critical management studies (CMS) (focusing on postcolonial concerns) and (2) business ethics (concerning stakeholder theory). There are two approaches to the study of marginalized groups in CMS; the first is to take a humanist perspective, which focuses on how social constraints limit human potential (Burrell and Morgan 1979). This perspective deals with subjective (radical) changes (i.e., changes that are not always visible) (Burrell and Morgan 1979). The second approach to apply a structuralist perspective, which I adopt in this article. The structuralist perspective focuses on the structural conflicts within societies that change political and economic dynamics (Burrell and Morgan 1979). This perspective deals with (radical) objective changes (i.e., changes that are visible or tangible) (Burrell and Morgan 1979). Some of the structuralist arguments made by several CMS scholars (e.g., Pal 2016; Girei 2017) are inspired by postcolonial theorists; therefore, postcolonial literature enriches our understanding of structural conditions in which such biases thrive. By structural biases here I mean whiteness and neoliberal ideology embedded into a system that aims to exploit the black people. Through this process, I believe that Western intellectual imperialism has fortified 
marginalization, and continues to exploit such groups in postcolonial societies (Ibarra-Colado 2006; Misoczky 2011).

From a structural perspective, CMS researchers argue that marginalized groups encounter power/knowledge barriers that exclude them from participation in any decisionmaking in institutional settings. In other words, by their very nature, institutional mechanisms are set to dominate; for instance, they are subject to imperialist ideologies, where marginalized groups have very little opportunity to influence the norms, values, and core activities of the institutions involved. In their study of soccer balls in Pakistan, Khan et al. (2007) showed how powerful actors such as MNCs, the United Nations and mainstream NGOs-as formal authoritative bodies of society - addressed child labor, which, rather than benefitting marginalized women and children, in effect worsened their situations (see also Khan et al. 2010). This marginalized group was affected because powerful actors did not consider the fact that the women who used to stitch footballs from home might not be able to work in factories for religious reasons; instead, they imposed their taken-forgranted norms and values on to this group as institutional beliefs. Thus, the women, who were dependent on stitching soccer balls for their livelihoods, became workless as a result.

When marginalized groups are affected by structures, their daily lives and freedoms of expression are affected adversely: Neither their wellbeing nor their lifestyle is in their control. In such circumstances, it is important to understand how their double-consciousness functions. Du Bois (1903 p. 8) describes double-consciousness.

It is a peculiar sensation, this double-consciousness, this sense of always looking at one's self through the eyes of others, of measuring one's soul by the tape of a world that looks on in amused contempt and pity. One ever feels his two-ness, - an American, a Negro; two souls, two thoughts, two unreconciled strivings; two warring ideals in one dark body, whose dogged strength alone keeps it from being torn asunder.

Although Du Bois (1903) uses the idea of double-consciousness in the context of the USA, it has wider application in other countries and contexts. It helps any marginalized groups of color not only to realize how purposefully 'race' is assigned to exploit and trivialize them, but also to be aware of any injustice they encounter because of such social construction of race. I define trivialization as ignoring or demonizing the marginalized people of color in dominant discourse and institutions, so that they feel valueless and disempowered or unrecognized in their everyday life. Such trivialization occurs through identity violation and dignity violation.

When powerful actors categorize marginalized groups based on gender, color, religion, and other categories (c.f.,
Medina 2013) this constitutes identity violation, which occurs because, through this process, powerful actors can stigmatize or entrap any vulnerable individuals into a particular classification and then formulate an appropriate strategy for exploitation based on the outcomes of this process. Hence, identity violation strengthens powerful institutions (c.f., Sen 2007), helping them to maintain their hegemony and dominance over marginalized groups through diverse flexible logics and mechanisms. For example, black Africans are treated as inferior humans (see Rhodes 1877). Such treatment was legitimized by creating an institutionalized belief that black people are savages and that, because of their racial inferiority, they must work under their white masters (e.g., Rhodes 1877). This categorization was developed and perpetuated over time so that some Western countries could exploit black people for status and wealth creation. According to Wesseling (1996), from a powerful actor's perspective when infighting is incited between marginalized groups, it benefits the powerful actor who can enjoy such resource exploitation sustainably.

When identity violation occurs, marginalized groups naturally become subject to dignity violation, which is when powerful actors treat them as powerless and irrelevant entities by excluding them from any institutional discussions (c.f., Medina 2013). Therefore, these groups lack opportunities to exercise their fundamental rights and freedom of expression (Nussbaum 2000; Nussbaum and Sen 1993; Sen 1999, 2005). When groups are restrained from voicing their pain, anger, joy and sorrow, their rights are not being respected.

This process is more subtle in the postcolonial era. These days, marginalized groups do not necessarily encounter direct colonial exploitation strategies (with exceptions), but they frequently experience hegemony, which Gramsci (1971) defined as the cultural and political manipulation through which powerful actors force marginalized groups to obey authorities and conform to dominant institutional norms. Said (1978) conceptualized how hegemony works in practice through his influential work on orientalism. According to Said (1978, p. 3), orientalism is

discussed and analyzed as the corporate institution for dealing with the Orient—dealing with it by making statements about it, authorizing views of it, describing it, by teaching it, settling it, ruling it: In short, Orientalism as a Western style for dominating, restructuring, and having authority over the Orient.

Said (1978) suggested that when marginalized groups experience cultural and political power/knowledge imbalance, this in effect perpetuates Westernized dominance in different forms and guises. Such dominant strategies-formulated and supported by imperialist logic and thoughts-also attempt to control and suppress the collective consciousness 
of marginalized groups. While CMS well explains how Westernized dominant structures prevent marginalized groups from becoming rebellious (e.g., Varman and AlAmoudi 2016; Munir et al. 2018) or, even if they do become rebellious, adopt reactionary strategies and protests (e.g., Daskalaki and Kokkinidis 2017; Pal 2016), it is naïve to believe that marginalized groups never exercise their (self) consciousness (by knowing their vulnerabilities) in thoughtful ways.

Evidently, the double-consciousness of Du Bois (1903) encourages marginalized black people to rebel against whiteness in their rejection of the continuing presence of neoliberal mechanisms designed to promote racism and exploitation. From this perspective, whiteness simply does not mean racial category; rather a "set of locations that are historically, socially, politically, and culturally produced and moreover, are intrinsically linked with unfolding relations of dominance" (Frankenberger 1997, p. 6). Whiteness has become "the invisible norm against which other races are judged in the construction of identity, representation, subjectivity, nationalism and the law" (Moreton-Robinson 2004, p. vii) and thus strengthens neoliberalism in the postcolonial era. Subsequently, the idea of double-consciousness not only portrays the vulnerabilities of marginalized groups but also to underpin the structural biases and conditions under which marginalized groups consistently struggle against whiteness (see also Allen 1994; Hill 1997; Medina 2013).

Interestingly, mainstream business ethics literature (such as stakeholder theory) suggests that aggravation of marginalized groups needs to be neutralized if powerful actors want to retain their moral claims and continue their activities in the form of stakeholder interactions (Mitchell et al. 1997). Without moral claims (Donaldson and Preston 1995), no one can retain legitimacy and no actor can dominate others forever (see, for example, Suchman 1995). Consequently, some stakeholder scholars include marginalized groups under the category of secondary stakeholders (Eesley and Lenox 2006; Frooman 1999), which affords corporate managers and institutional administrators some guidelines about how stakeholder value must be defined, created, and distributed (Mitchell et al. 1997). Stakeholder value creation can be defined as the societal and economic gains that firms distribute among their stakeholders (who are affected by or can affect focal firms) (Freeman 1984). Normatively, stakeholder scholars suggest that powerful actors distribute such values fairly to all stakeholders with some tradeoffs (Harrison et al. 2010), although CMS scholars consistently show that such tradeoffs have little significance for marginalized groups (Khan et al. 2007), and even bring them further misery (Chowdhury 2017, 2019). This situation is perpetuated, enabling powerful actors to become more influential and to continue to dictate how marginalized groups should live their lives, thus restricting them from expressing their grievances against injustice (e.g., Ehrnström-Fuentes 2016). Exploitation becomes so strong and normal in societies that marginalized groups find it hard to challenge such injustice.

In the above context, it is not surprising that marginalized groups would become more aware of the white dominance that they experience in various forms, particularly through neoliberalism and hegemony. Therefore, it is inevitable they would (want to) retaliate against the whiteness. More specifically, I argue that marginalized groups are not consciously naïve (see also Morris 1984, 2015); they clearly understand the challenges that whiteness poses to them (Du Bois 1903). However, CMS scholars do not clearly suggest how the consciousness embodied in moral values, pain and love is mobilized through a complex web of emotions. This can also be a driving factor for fighting whiteness in a sustained manner-for example, when a temporary goal is achieved, such as the removal of Rhode's statue. In other words, rebelling against the experience of double-consciousness is a continuous process which encourages one to liberate oneself from colonial legacies or neocolonial mechanisms. This is not achieved through a one-off or temporary success (e.g., through the removal of a statue) because black people's consciousness about the racial oppression they face is not developed in just a day or over a few weeks: It is an ongoing process through which their emotions and anger against their oppressors accumulate over time. If we consider temporary success as the major concern of marginalized groups, the rejectionist perspective would not have any value: Marginalized groups are excluded from the academic discourse.

Thus, when marginalized groups come together to mobilize a movement, they must not be simply seen as a reactionary group; they are conscious of their identity, rights, and dignity (Morris 1984, 2015). They are politically conscious and care about justice and freedom from the perspective of their double-consciousness. In other words, marginalized people have epistemic awareness of how they want to fight injustice (Mignolo 2009). To achieve this, they not only perform an epistemically disobedient behavior; they also mobilize it in their everyday lives and struggles, which helps them to develop a rejectionist perspective against powerful actors, structures, and rigid societal norms. But then an important question arises: How do marginalized groups mobilize a rejectionist perspective and maintain it over time? I address this research question in the context of South Africa and the RMF movement. 


\section{Context and Methodology}

\section{The Rhodes Must Fall Movement}

A fundamental concern of the RMF movement was Rhodes' strong belief that the Anglo-Saxon race was "the finest race in the world" (Rhodes 1877). Rhodes further claimed:

Africa is still lying ready for us it is our duty to take it. It is our duty to seize every opportunity of acquiring more territory and we should keep this one idea steadily before our eyes that more territory simply means more of the Anglo-Saxon race more of the best the most human, most honorable race the world possesses (Rhodes 1877).

His belief not only dominated his political ideology but also how he conducted his business and exploited slaves. His views about colonialism and slavery were not only racist, but deliberately exploitative, as he explicitly stated:

We must find new lands from which we can easily obtain raw materials and at the same time exploit the cheap slave labor that is available from the natives of the colonies. The colonies would also provide a dumping ground for the surplus goods produced in our factories (Rhodes citied in Ellwood 2004, p. 13).

His beliefs and legacies were symbolized in his statue, which angered young black South African students at UCT and motivated them to question the very presence of a Rhodes statue on their campus. Such questions led some of the activists, such as Chumani Maxwele, to challenge the authority of UCT by demanding the removal of the statue (Fairbanks 2015). Maxwele (Maxwele cited in News24 2015) notes:

"[Rhodes] dispossessed and killed black people. His footprints are all over our country. You can't even talk about mining in this country without invoking Rhodes. Remember how people in mines were treated, like they were in [concentration] camps? All thanks to Rhodes... Why on earth do you want his statue to remain? To remind us of what he did to us?"

Maxwele (cited in News24 2015) further emphasizes: it was not just that "Rhodes didn't want black people". "[At] some point, UCT also didn't want black people. Remember Professor [Archibald] Jordan, remember Archie Mafeje, remember Professor [Mahmood] Mamdani." For example, in 1968, UCT refused to give Professor Archie Mafeje a teaching position by citing apartheid law and, in the late 1990s, again failed to appoint him in the university (see Hendricks (2008) for more details). This was not surprising given that in 1923 UCT's Council declined to admit "native or colored" students (Perez et al. 2012). However, when black students were eventually admitted into universities, their participation in sports and social activities was restricted. From 1959 to 1985 black students were required to obtain permission from the relevant Minister to attend white universities such as UCT (Tobias 1980).

Therefore, the RMF movement contends that their demand was a challenge to the entire colonial legacy and the injustices that still pervade South Africa's socio-economic and political lives (see Chaudhury 2016). Maxwele (cited in News24 2015) concluded:

Let's not wrongly personalize the issue and detract from the big picture. This thing is about black people. It is about the history of black people; it is in front of you. It is a political blunder that this issue is even up for debate. In this country, we artificially dance around race and racism and don't address it.

After Maxwele threw human feces at the statue, various types of protest took place at UCT, including civil disobedience, occupation, and students storming the Bremner building (the UCT administrative office) (Pather 2015). Although the movement was initially about the removal of the Rhodes statue, it expanded to address the issues of student accommodation and tuition fees, which led to an extended campaign called Fees Must Fall (initiated in midOctober 2015; Gasa and Dougan 2016; Van Der Merwe 2015). RMF instigated debates on the low representation of black students and faculty staff at UCT, among others. For example, UCT lecturer Xolela Mangcu pointed out that only five out of the 200 senior professors at the University were black (Petersen 2015). This also triggered a backlash against the elite white South Africans by the poorer section of black communities, as the latter were not enjoying the expected (and promised) benefits of socio-economic freedom in the aftermath of apartheid. Interestingly, during the RMF movement, a group of students demanded the removal of a statue of Rhodes from Oriel College, Oxford University in the UK. Unlike the RMF in South Africa, this movement failed to influence the University authorities and the statue remains in place (Rawlinson 2016).

\section{Positionality and Context of the Interview}

While the removal of the statue at UCT became a significant issue, such a process - which some observers describe as symbolic_cannot fully explain the RMF movement. To understand the different aspects of the movement and their inherent meaning, I contacted several UCT student activists during March 2016, the month which I spent as a visiting scholar at the University of the Western Cape (the University 
was created in 1959 to achieve the segregation of higher education in South Africa-i.e., students of color were only allowed in a few non-white universities). Some of the UCT student activists who I reached out to were reluctant to give interviews, as they did not want to engage with an outsider researcher like me (even though I was born and raised for almost half of my life-until that time-in a South Asian country). The students were concerned that I was Cambridge University graduate and working (at the time) in a leading Irish University. More specifically, they were concerned that external actors, even Western-trained researchers of color, could easily misinterpret the movement. A few students clearly articulated their reluctance to be part of a RMF study when I attended a student procession at the UCT campus. During this long procession I was able to converse informally with some black students and later connected with them through social media platforms. Although these students did not want me to study the RMF movement, they were very frank about their opinions. Thus, our conversations did not create any expectations, tensions or frustrations. I was even allowed to take a significant number of pictures of the publicly held procession and meeting. In the end, after significant effort, I managed to secure an interview with UCT Master's student Brian Kamanzi (hereafter BK), who played a leading role in the RMF movement. His full interview is available in the end of this article. Here, it is important to note that I was able to connect with BK through a white South African student whom I met during my teaching of a Master's course in Ireland.

Although I am a researcher of color and deeply concerned about postcolonial legacies that I closely observe in my birthplace (obviously in different forms compared to South Africa), I do not claim to champion the struggle of black students. While I hold a personal perspective that I aligned with the core ideology of RMF, I do not claim that I hold a fuller understanding of the RMF movement or that I have liberated myself fully from the white privileges and complicities that underpin the movement (the fact is that I trained and have taught in leading Western institutions). This is because, from the perspective of positionality (Cruz 2014), I think I am unable to interpret some of the emotional aspects shared among black students which are difficult to realize from an interview or from observation of a procession. In other words, there were subliminal nuances which an outsider would find difficult to observe (Katz 1993). However, ideological alignment with RMF movement provides an opportunity to represent the movement more adequately because ideological mismatch often generates a very different narration of a resistance (den Hond and de Bakker 2007). This alignment is important because, as Medina (2013) claims, often, even most liberal whites (or in my case a Westerntrained brown researcher) may not understand the issues that are significant to the black people but insignificant to their white counterparts. From this perspective my intention is not to claim a whole truth but to highlight a partial truth (Kaplan 2002) through challenging Western bias (Connell 2007) that exists in management and business ethics research and is a major barrier to developing southern theory.

While BK discussed various aspects of the movement, it should be noted that his audio-recorded interview was given as an individual activist. His interpretation of the movement is personal and must not be seen as a collective view. This is the basis on which I had permission to conduct the interview; thus, I want to eliminate any confusion that may arise from my interpretations based on BK's interview. While I interpret BK's views to develop the idea of the rejectionist perspective, such conceptualization requires further exploration and refinement.

The most important justification for my choice of a single respondent is that BK's interview offers a deep understanding of colonial legacies and racism in the context of RMF and thus opens an opportunity for multi-level interpretations and conceptualization of black students' struggle in Africa. Although BK's interview holds personal accounts, such views resulted from his deep immersion in the movement, which affords me an opportunity to locate where an individual's (black) consciousness truly holds power and how it is mobilized in the postcolonial era.

I admit that it is beyond the scope of this article to conceptualize issues with certainty from a single interview as such qualitative research comes with limitations (see, for example, Jack and Westwood 2006; Smith 1999). There might be other relevant issues in the RMF movement which were not captured; however, this one detailed account was an important starting point. This account can trigger a debate in academic space, so that we may talk about colonialism, slavery and racism with an open mindset and bring alternative voices into academic journals.

The above move is particularly crucial in the field of business ethics, which could advance so much more by addressing some uncomfortable truths, such as the colonial logics embedded into MNC activities that encourage profitmaximization at the expense of marginalized-group capabilities' development. For example, the International Labor Organization (1964) revealed that during the apartheid era, there were two separate labor laws for whites and blacks. Accordingly, black workers were excluded from collective bargaining-i.e. black unions were never recognized by the apartheid regime. In addition, violent suppression of strikes by black workers was common. Because of separate laws and dominance of the white economy, in 1975, for instance, a black worker in South Africa's coal mines earned ten times less than a white worker earned (Du Roy 2013).

None of these inequalities was possible without Western/ foreign investments, which at the time controlled $80 \%$ of South Africa's industrial capacity, particularly in the mining 
and gold industries (Du Roy 2013). The MNCs' historical dominance in South Africa through foreign investment still enables the white economy to flourish while maintaining income inequalities which, in effect, significantly disadvantages the black population (Ahman et al. 2011). Accordingly, the RMF movement argues that the white economy has remained untouched even in post-apartheid South Africa (Hickel 2015). The South African government led by the African National Congress (ANC) was unable to reform the white dominance that prevails through neoliberalism from which MNCs benefit but black people continue to suffer. For example, even until the 2007/2008 financial crisis, South Africa was considered one of the most unequal countries where the poorest $20 \%$ of South Africans received $1.6 \%$ of total income while the richest $20 \%$ benefitted from $70 \%$ (South African government's development indicators 2009 cited in Ahman et al. 2011). While this continuation of income inequality fueled social inequalities, one must recognize that all these inequalities are rooted in centuries-old racial oppression or white dominance, in which Rhodes played a major part. Therefore, to advance decolonized knowledge creation, even today, we must deal with uncomfortable historical facts when we study organizations, movements and injustices so that epistemic struggle through disobedience supports movements such as the RMS to work towards a much-needed just society.

\section{Interpretative Mechanism}

I shared the interview transcript with BK to ensure transparency and avoid any misrepresentation. BK suggested a South African UCT student to transcribe the interview. One of the problems with the transcription was the inadequate use of punctuation marks (full stop, comma, semi colons, etc.). Therefore, I had to spend almost 2 weeks correcting the transcript. I also asked a professional editor to read this interview to identify any remaining grammatical mistakes and edit those mistakes without changing the meaning of the discussion since English is not my first language. This process was very transparent, and I did it with the consent of BK.

Articles based on a single interview are not unusual. Management scholars (e.g., Chowdhury 2017; Chowdhury et al. 2017; Chowdhury and Willmott 2018; Muhr 2011) have previously developed their work in such ways. The reading technique I employed to understand the interview was emergent in nature because when I was correcting the punctuations, I re-read the unedited interview several times and noted the many questions and theoretical concerns that came to my mind in a separate document. At this stage I also marked some questions for BK so that I could cross-check some information with him. These questions and concerns later helped me to develop my initial thoughts about the
RMF movement and provided a solid ground for formal analysis of the interview.

To formally interpret BK's interview and develop new theoretical insight (see, for example, Sveningsson and Alvesson 2003), I read edited versions of the interview script in depth several times. Following Strauss and Corbin (1998), initially I applied open coding to the interview. Open coding is evident in the Findings section where I used chunks of short and long quotes from the interview. I integrated and connected them to axial coding and thereafter aggregated them into four main themes. These themes are (1) black pain, (2) decolonizing space, (3) equal representation through epistemic disobedience, and (4) epistemic disobedience that fortifies the rejectionist perspective. While the themes of the article offer a unique and coherent argumentwhich helped me to develop a theory of the rejectionist perspective - throughout the reading and writing of this article, I tried to get a deeper sense of the individual threads of the interview rather than becoming overwhelmed by detail. Simultaneously, I also consulted secondary sources for contextual and historical information related to South Africa and the RMF movement. Since the issues of racism and colonialism are sensitive in nature, I do not claim that my interpretations are superior or flawless; rather, I suggest that my arguments should be further discussed, challenged, and extended to enrich a new avenue of research on black pain, consciousness, and the rejectionist perspective.

\section{Findings: Beyond the Removal of the Rhodes Statue}

BK offered various perspectives on the movement. All his quotations are depicted in italic font for clarity. It is imperative to highlight four interrelated themes that were conceptualized while his interview was analyzed. These themes are interrelated because they reveal how racism embedded in colonialism has created black pain and subsequently made black people aware of the need to decolonize knowledge. As a result, the fight against 'whiteness' was not just about a fight against neoliberal elite actors; it remains a constant and ongoing battle against a structure that has perpetuated racist thoughts and acts for centuries-and continues to do so. I argue that the rejectionist perspective needs to be embedded in epistemic disobedience to fight such a structure since whiteness is grounded in hegemonic ideology that needs to be fought and replaced.

\section{Black Pain}

BK discusses "black pain," which can be defined as "the psychological and physical experience of having to live as a human who is subject to inhumanity." More broadly, 
black pain "relates to setting up an antithetical argument and resolution of the master-slave dynamic. It says that South Africa was constituted through colonialism. Colonialism was deigned to maintain white supremacy and the hierarchy of racism. "Humanity" was benchmarked then by the white male, hence the "universal" and "objective" standpoint was European. "Inhumanity" is, thus, embodied by blackness, and black pain is the psychological and physical experience... On the one hand, you have the psychological trauma of experiencing white supremacy in age of neo-liberalism; on the other, racism exists but, by white definitions, without racists. You can see here all the elements of white supremacy in the context of UCT-not that different to 30 years ago. However, people with clever language can now evade responsibility for what is very clearly a problematic and racist society."

BK explains black pain as a wound caused by colonialism and racism that is still a constant reminder of the past. While black pain affects individuals' identity, it also shapes their consciousness when they seek access to institutions, work for organizations, or simply try to carry out a normal life. In other words, the meaning of black pain is inseparable from the black self or soul (c.f. Adell 1994; Gilroy 1993). However, black pain can also become a source of power, enabling people to overcome the fear that they will easily fall victim to or remain vulnerable to racism, institutional domination, or the misinterpretation of others. Thus, when black pain is integrated into one's soul, it influences a person to act in unpredictable ways: It can make one brave enough to challenge others assertively. This confidence gives sufferers of colonialism and racism a sense that, despite being marginalized, they can raise their voice against others. They must not show unquestioning obedience to authority and must challenge powerful institutions that carry colonial and imperialistic legacies.

Thus, when black pain is mobilized, it is likely that powerful actors will react. For example, BK points out: "now that the groups were coming together, there was a lot of backlash from conservative whites who called this mobilization "barbaric"." Such reactions make it apparent the mobilization of black pain is essential for the drive for decolonization. BK emphasizes: "Rhodes was used emotively as representing the root of the matter, his legacy being the colonial experience for black people in South Africa, and that the black pain you are experiencing here is a direct result of colonial conquest. So, you could say the psychological remedy for the pain is decolonization-hence, the removal of the statue. Perhaps it should have been the destruction of the Rhodes statue; a catharsis to the subjugation of Rhodes' project. This would create space for something else to develop and for people to live." But how can such "space" be created and maintained when black South Africans are subject to humiliation and inhumanity? BK explains through his notion of decolonizing space.

\section{Decolonizing Space}

If colonialization means imposing an ideology, a culture, or a system that takes away people's freedom to think and act freely and disobediently, decolonialization of a space mean liberating someone's self from mental and physical captivity. It means not seeing black pain as a wound, but rather as an opportunity to raise one's voice. Thus, the decolonization of a space cannot be achieved through the removal of a statue alone; it is also about getting access to equal opportunities and representation in every sphere of societal and organizational life. Such opportunities and representation must be secured and grounded in law as human rights, not as ad hoc freedoms, where others would claim that they are giving away some opportunities and rights because they are sympathetic to black lives. Henceforth, decolonialization means challenging the education system, curriculum, and stereotypical image of black people, and fighting economic inequalities, not only collectively, but also through individual souls in and around institutions. Ultimately, this constrains powerful institutions from imprisoning black souls (feelings that shape the ideologies of black persons) and thoughts and dreams.

Decolonization of space is not easy. If we examine the RMF movement itself, it shows how complicated the process can be, despite some attempts to do it. For example, BK states: "the method of occupation was central to the conceptualization of the politics. This also represented the space in which the thrust for decolonization was acknowledged." Furthermore, "[our] methodology included disrupting lecture spaces; we avoided holding our events at elite venues and even tried temporarily occupying spaces such as reception areas by having reading groups there..." When initial internal consultation and agreements occurred, political collaboration or solidarity was developed. BK, for instance, cites examples of such political collaboration: "there were groups like Palestinian Solidarity Fund, Worker Left Form, Left Students Forum, and 'Imbizo' which was related to a youth group of the pan-Africanist Congress called PASMA, and they had already been running dialog sessions at one of the residences."

One of the obstacles to decolonizing space, though, is that many powerful actors simply do not understand what RMF means. While such responses are sometimes strategic, some powerful actors were entirely ignorant of and insensitive to the demands of black students. BK narrates this peculiar situation: "It was clear that a lot of the administration (even some of the white academics, although they won't admit it) didn't understand the intellectual questions raised by decolonization and what it is that we are asking for. They tried to 
convert all our demands into some kind of tangible desirethe statue being one of them-to work out how to appease these angry students: "If we just remove the statue, hopefully the aggrieved students will be fine." They just weren't getting it. There were fairly complex existential arguments about space, the nature of the curriculum, and the role of the university. It was a "Can the subaltern speak, now?" moment; we felt we were saying many sensible, complex things but nobody was listening to what we said or reading what we wrote (through statements) in the public space. Everybody was just analyzing our actions. Even academics, when they speak about us, don't refer to our statements which are often lengthier than their articles."

This ignorance and insensitivity encouraged the UCT administration to be unsympathetic to black students because the authority thought that the movement was over as soon as the statue was removed. But decolonization was not simply about removing a statue-it was more about removing colonial legacies from the institutional mechanisms that dominate black students' lives. BK elaborates: "UCT actually had a policy during apartheid that they would never bring police into the campus. That was their commitment. It was broken on October 20, 2015, I think, with us. They brought police into the campus and evicted students. It spiraled into a situation where police were just there to pick up students. There was a lot of fighting: Police coming in with stun grenades and targeting students." This violence continued when UCT hired a private security firm. BK explains: "During exams, UCT hired a company called Vetus Schola, which was also doing work at University of Western Cape. This company was much more violent than the police. You could see that the strategy of how to deal with the protests had been conceived at Wits [University of Witwatersrand] and at UCT and instrumentalized at the other campuses, Wits being one of them. When it is instrumentalized, it gets worse; you see the uglier elements at the universities that have more working-class people."

BK suggests that "UCT had the lighter, "civilized" version of what would be happening elsewhere in South Africa. Private security firms came in and UCT paid them ZAR $2 M$ per month. Their personnel can be pretty messed up, as some of them have said openly. A couple of them had been white mercenaries and spoke about having fought in Angola-a crazy situation with provocations left, right, and center. The university's own security service wouldn't touch the students because a good relationship had been established during previous solidarity efforts. They had, so to speak, been turned. Thus, UCT had to bring in an objective, third-party provider that had nothing to gain from the struggles on the campus, making it easier for them to exercise the necessary repressive force."

BK also finds the role of national and international media disturbing; they ignored the facts and focused on sensationalizing the stories. BK recalls: "many instances with the local media where they wanted to get statements. They asked whether we had a spokesperson. When we said no, they would identify whoever was speaking as a spokesperson because they were just not willing to accept our way of organizing and expressing ourselves. They were trying to force structure upon us-in the same way that society itself is structured. For example, society prefers to see male leaders. Media gravitates toward the men to speak by quoting or emailing them for an interview whilst ignoring women or transgender people in the space who are raising intellectual questions. Decolonization becomes associated primarily with some random guy who is chanting "Kill all whites" instead of the 30 or 40 points that were raised by the transgender women. Why does the media choose to go to with the random guy in this case? I have no doubt that there is no such thing as media objectivity. Maybe, for a couple of the South African media houses, we have been the goose that lays golden eggs in that people want to read what is happening, but they sensationalize a lot of stuff and they take things out of context."

This account clearly indicates that it was a difficult task to decolonize a space physically and psychologically alongside which the movement had to exist and sustain its activities. In other words, dominant institutions still practiced colonial strategies in different forms that hindered the decolonizing process. Thus, a fundamental concern of the RMF movement was how to mobilize epistemic disobedience in such a challenging context.

\section{Equal Representation Through Epistemic Disobedience}

BK raises an important issue about how equal representation can be achieved in such a way to make the decolonization of space viable. He thinks that, to achieve equal rights and representation, a black person has to be epistemically disobedient. Qijano (2000) describes epistemic disobedience as a process through which one challenges the notion that Western modes of thinking are universal. It also means "de-linking from the magic of the Western idea of modernity, ideals of humanity and promises of economic growth and financial prosperity" (Mignolo 2009, p. 3). Therefore, epistemic disobedience requires "epistemic de-linking," so that one is not trapped within Westernized ways of knowledge production and acting. In the context of RMF, while epistemic disobedience means challenging the authorities, institutional racism, and colonial legacies, it also means taking practical actions to de-link one's soul from the dominant practices established through colonial thoughts. If black people do not take practical actions to de-link from such biases and knowledge, they may find it challenging to become epistemically disobedient. In other words, black 
individuals have to transform their own past and legacy into real power in order to rebuild themselves, particularly given that institutions - such as universities or legal and political systems-are not without complicity and are not free from colonial influence and knowledge (Hamer and Lang 2015).

From the above perspective, demand and activism for free education, for instance, are crucial elements that will strengthen epistemic disobedience in the long run. On one hand, free education can help a deprived black population to know their history better, teaching them about how to be aware of and reject misinformation. On the other hand, free education limits the influence of colonized ideas such as scholarships that normally encourage black students' dependence on dominant institutions. BK details this process:

I think that education should be free. I think the fact that there are scholarships is an aberration. I think that they contribute to uneven distribution of political and social power. The Rhodes scholarship is actually one of the finest examples of that. It is complicit in producing global elites within the Third World who hold a monopoly on knowledge. It also gives elites access to governmental power. It is like a rubber stamp for life that you are going to be an important person as a Rhodes Scholar. Of course, it's a certain kind of Third World hook for whoever manages to make his way through. Similarly, I think Rhodes' legacy permanently damages physically and epistemologically the space in which he operated and overcame, so to say that he contributed to equality is backwards."

According to BK, the above process means that "we have to do the equality work. We have to repair what he has done in the space. We cannot be penalized and we do not have to thank Rhodes for the skeletons of his project that he left behind for us to reconstruct our society. People say that he "donated" the land. But if you call into question the very notion of "private" when describing the principle of property in our society, then how can you credit him for donating that which he should have never taken? If you look at the university infrastructure itself, an important question arises: Who built the university? In fact, Rhodes is quoted as saying that he built the university out of the "stomachs of kaffirs," one of the most vicious and derogatory phrases to describe black people in our context. It was black workers who built the university. Who owns the product and the labor? For sure, Rhodes did not pull those stones up the steps that I walk on. He may have provided certain ideological boundaries or tools with his architects, but it was the laborers who at the end of the day played the most significant role in creating that space. I think that it is precisely these reasons that we are able to embody those works and give them different kinds of meaning. It's not necessary that we have more universities like UCT to have an equal society; UCT could burn down tomorrow and we could still have an unequal society. It's a similar thing with the Rhodes scholarship; we don't need the Rhodes scholarship to have a more equal education system. There are many other ways to achieve that. It's backwards to say that Rhodes' contribution-the emphasis here is in particular on what has been done to the colony - has to be weighed against his imperial legacy: His contribution to creating things like race in particular and the differentiation in class is irrecoverable. The benefits of any society belong to those who struggle for it and not those who act against it."

Importantly, mobilization of epistemic disobedience requires more than internal and external discussions; one must challenge those who create unnecessary tension for the movement. BK stresses: "there has been significant tension brewing between younger South Africans and the older generation because the older generation is saying, "You guys are disrespectful" whilst the younger generation is saying, often without fully appreciating what happened, "They sold out." Opinion is divided on the notion and role of "respect" and so support for the movement has definitely been skewed as a result." While these types of tension exist in different forms in every movement, the RMF movement demonstrates how dogmas and fear within the black community can be rejected, thereby highlighting the power of black consciousness. Even then BK is not sure whether the RMF movement is successful for simply removing the statue or fighting paternalism against the movement; he does, though, concede that it is a starting point of a revolt against an unjust system that will challenge the powerful authorities. This process is lengthy and requires consistent debate and activism in and around institutional and civil society spheres.

\section{Epistemic Disobedience that Fortifies the Rejectionist Perspective}

To downplay the influence of the movement, critics raise a question: What had really been rejected by the RMF movement? Uncertainty arose because "[everybody] was questioning the point of removing a statue". The removal of a statue may not be vital; instead, it is the decolonization of the space that was crucial. However, BK finds this odd: "They were not just saying what is the point of removing it, they were saying, "No, don't touch it. It does not mean anything to remove it." But, clearly, it does. There is a reason why those statues are built in such a way that it's difficult to pull them down. I think statues in that era were built with the understanding that the political climate would change and they believed that they would outlive the world, like some maniacal fantasy. They believed that we would defy at some point." 
While BK “[doesn't] necessarily believe that destruction of artifacts is the way to achieve a [social] change. However, [he thinks] that these kinds of things are a manifestation of change itself and the removal of a statue provided [them] with a strategic device which, in effect, enabled [them] to articulate many issues that meant different things to different people. In the idea of removing the Rhodes statue, people saw their own meanings expressed through different emphases, for example how gender is constructed in colonial reality, or how migrant labor and capitalism functioned. It was a good learning device for many issues and I feel that we all learned a lot from this exercise."

The above experiential learning was important because it gave many students the confidence to exercise their consciousness and eliminate self-doubt, characteristics necessary for fighting the negative implications of colonial legacies in present-day South Africa. This step is particularly important for the RMF movement because it is difficult to be epistemically disobedient without knowing the real historiography of South Africa and colonialism, which is practically non-existent in academic curricula both in schools and universities. BK recalls: "during [his] high school years, they stopped offering history. After Grade 9, even if you wanted to take history as a subject, they stopped offering it up to the matriculation level [Grade 10] because nobody was talking about it. They wanted to emphasize the math and science because a high-skill economy needs engineers and doctors. I think that there is something to be said here about a movement-youth movements-asking particular questions about history because we are a fairly uninformed society when it comes to our own history. I think persistent inquiry into the past is necessary so that we don't repeat our mistakes." If past mistakes are truly learned about through the grand project of epistemic disobedience, then only after this process has taken place would "undermining the entire project of UCT" be viable.

\section{Discussion and Conclusion}

\section{Implications of the Rejectionist Perspective for Moral Learning}

While a number of CMS scholars influenced by postcolonial theory (e.g., Jack and Westwood 2006; Özkazanç-Pan 2012; Pal 2016; Rhodes and Westwood 2007) talk about challenging colonial legacies and deconstructing the processes of knowledge reproduction to highlight structural problems (see also Dabashi 2015; Said 1978; Spivak 1988, 1999), RMF is a great example of how marginalized black students address such concerns in practice. For example, the RMF gained public voice and challenged the authorities in a unique way, by which I mean that the rejectionist perspective of the RMF movement indeed influenced a wider sphere and touched upon issues such as free education, student accommodation for poor black students, labor rights, corruption, and inequality. The rejectionist perspective is not just about rejecting taboos [e.g., "blackness symbolised evil, demise, chaos, corruption, and uncleanness, in contrast to whiteness which equalled order, wealth, purity, goodness, cleanliness, and the epitome beauty" (Moodley 1991, p. 237)]; it is also about rejecting dominant institutions and exploitative capitalism. The rejectionist perspective emphasizes that black people must not be portrayed as inferior and full of selfdoubt while they challenge dominant institutions; they are fully capable of thinking, articulate, taking action and protesting for themselves. Here, the rejectionist perspective fundamentally challenges the whiteness that is embedded into societies' formal and informal institutions, norms, politics, language, culture and socio-economic structures.

The above discourse confirms that marginalized groups know (although their knowing is continuously trivialized by powerful actors) how to mobilize resistance against the experience of double-consciousness that underpins the rejectionist perspective. For South African black students, double-consciousness is two ways of seeing themselves. On one hand, they are not outsiders in their country; however, they are victims of colonial and racist oppression on their own soil. Thus, their status as victim constantly reminds them that they are imprisoned in their homeland through the deeply rooted whiteness. They understand that whiteness is deeply embedded within the socio-economic system and becomes a norm such that exploitations are normalized and reoccur as a natural phenomenon. On the other hand, they still find that their identity disadvantages them in a place/ nation where they are supposed to be free and happy. Powerful actors categorize them and make them feel irrelevant. Even when a black person is identified as a valuable citizen, their ideology is shaped in a way that they are not necessarily free from the personal whiteness (e.g., white norms and culture that they are forced to adopt and practice in their daily lives) that they experience because of structural conditions in which they interact with powerful white actors and institutions (Du Bois 1920). Since whiteness is deliberatively imposed on a non-white person and can force a black person to act like a white one (see, critically, Dabashi 2011; Fanon 1967), such manipulative infliction of white ideology and hegemony can imprison the souls of black people.

BK reinforced that black students are aware that 'twoness' has its dark sides. They had learnt well from past experiences how whiteness works and how it can stifle black people's desire for freedom. This ever-present possibility that the dark side of 'twoness' exists does not mean that marginalized black students remain silent or inactive; rather, it creates a peculiar anger among these students, which is not driven by hatred. Their anger makes them more conscious of 
their rights, given that they do not wish to violate other people's rights, which means that black students demand equal rights for all, irrespective of race, religion, and any other identity-based stigmatization. When they are angry, it does not mean that they are violent; rather, they seek to convey a message of love by offering the possibility of a peaceful community. For example, a group of transgender students at UCT thought that they were excluded from the RMF conversation. However, as soon as the RMF movement became aware of this grievance, its members fully incorporated those transgender voices into its discourse and stimulated wider discussion to develop greater harmony and solidarity.

BK emphasized that ultimately black students seek a greater autonomy (c.f., Graeber 2004; Sellers 2004). This autonomy does not mean just emancipation-it also embodies the capabilities to reshape the collective memories and undo the unjust experiences of the past to subscribe to and establish a greater democracy. In other words, the movement wants justice for all. For example, the demand for free education is not only for poor black students, but for all students. To achieve their goals, however, they need to internalize epistemic disobedience and mobilize the rejectionist perspective so that Westernized institutional dominance does not hinder the path towards this desired justice.

If colonized dominant institutions are not replaced, injustice will endure. Therefore, the RMF movement must have some success. But, according to BK, as the focus of the RMF movement expanded, it started losing its momentum. I contend, though, that a loss of momentum should not be seen as a weakness. The ideals of influential movements challenge different aspects of injustice, which are interconnected. Since injustices are embedded in societies' structures and constrain human capabilities, they have to be challenged (Du Bois 1903). Nonetheless, this is a long-term process that does not end in one wave of protest. Instead, the rejectionist perspective is disseminated through such movements and everyday struggles, and consistently challenges various aspects of dominant institutions. This perspective makes marginalized people (more) aware of injustices and encourages them to challenge dogmas.

Henceforth, the effects of epistemic disobedience channeled through the rejectionist perspective were more widespread through the movement than one could expect. The rejectionist perspective, in this respect, is a learning process through which a black soul liberates themselves. This soul does not rely on others or cry out for help. This learning experience has an enduring effect, because it helps someone not only to liberate themselves, but to ultimately encourage future generations to share decolonized ideas. This is the basis on which the RMF movement triggered various mobilizations such as free education, strengthened labor and women's rights, and fought against corruption.
Since the moral learning of the rejectionist perspective is a continuous process of mobilizing epistemic disobedience, it can reappear or reoccur in different forms, shapes and acts (psychologically and physically) over time. This means that, through free thinking (without taking dominant institutions and whiteness as for-granted and unchallenged), a person captures a space (even if occupation of this space is insignificant to powerholders but shows that a marginalized person can think freely) where their voice will bring potential for change-no matter how small that change is. It means that physical occupation is as important as psychological freedom (Fanon 1961). For example, the removal of a statue is not just a physical act; it is also a psychological one. It is the moment where liberation of a soul through a consciousness permeates others and has positive effects on societies (Chowdhury 2019). As a result, I postulate that an important implication of the rejectionist perspective is a continuous process of decolonization through which a person achieves representation of their true self and the courage to engage with multiple truths. Whatever a truth is (because a truth can hold multiple meanings for one person while making others uncomfortable), a person should have the ability to express their opinion and break epistemic boundaries and legacies.

In the end, while removing the statue was a significant achievement, the processes of learning, decolonizing spaces, and gaining further knowledge about oneself and the portrayal of black consciousness increases the possibility of freedom and justice. The true success of the RMF movement is not only explicit but also implicit in the sense that real success is all about consciously continuing the battle, even after the removal of the statue, so that epistemic disobedience permeates the rejectionist perspective in everyday life. The multiple effects of such a perspective should shape everyday political imaginations, forming a space where marginalized people 'imagine the unimagined' in their everyday lives and practice the unimagined fearlessly by occupying a personal space through psychological and physical means.

Although it is a constant struggle to maintain the rejectionist perspective-at least through the re-imagination of politics and imageries of diverse sets of activism - the everyday fight against whiteness and neoliberalism must continue. Such ideology is the foundation upon which the rejectionist perspective can be maintained irrespective of the practicalities and mobilization strategies that it is necessary to adopt in different times and spaces.

\section{Implications for Critical Management Studies}

CMS scholars need to consider how they address the issue of marginalized groups in different locations and contexts, and how they teach and practice issues such as black consciousness. This is particularly important because even CMS scholars can easily fall into the trap of whiteness. They can 
be complicit in creating-or become imprisoned within-a structure that was purposefully built to perpetuate whiteness. I raise this point because the RMF movement highlights the fact that although academics may feel empathetic or concerned about certain issues they may champion, they are not always sensitive to them. Therefore, I argue that the task of CMS is not to generalize the feelings of marginalized groups (c.f., Chowdhury 2019); rather, CMS scholars must design curricula and shape their intellectual work to include marginalized voices. In other words, CMS scholars need to adopt authentic pragmatism. I define authentic pragmatism in this context as a strong stance against racism and colonialism by working with marginalized groups in their efforts to decolonize spaces in contexts such as universities, curricula, fieldwork and day-to-day interactions with common people.

Authentic pragmatism can be implemented if CMS scholars fight color blindness and racial bias in academia, which are both still practiced in subtle ways, even within CMS (Bell and de Gama 2018; Bell et al. 2015; Tatli 2012). This is because structural conditions may still make one arrogant about and ignorant of the issues of marginalized groups (Medina 2013). For example, by flagging up corruption as a well-known problem, an academic told me that there is no value in researching or writing about the RMF because nothing has changed in South Africa because of the RMF movement. I wondered why this biased remark had been made. How can one know what has been achieved until someone studies a phenomenon? One reason for this comment could be that the movements of marginalized people (such as black people) are often seen as one-offs in contemporary society. Even when they make progress in their fight against 'whiteness,' marginalized people's pain continues to be largely ignored, misunderstood or trivialized, or even appropriated (when understood by powerful actors) to violate their rights and dignity. Academics' and powerful actors' complicities often create further barriers for marginalized groups to achieve their long-term objectives (Bell and King 2010; Chowdhury 2017; Ulus 2018). The RMF movement, for instance, highlights the complicity of UCT through the use of a private security firm to restrict black students against accessing their representational rights. Even appointment of an insignificant number of black academics also hinders justice. The implication is that subtle biases or stigma become entangled in both the academic structure and the imagination resulting in little incentive to conduct research on marginalized groups. Even when a study on marginalized groups is conducted, academics can be made to feel they are wasting their time on irrelevant issues.

To implement authentic pragmatism, it is essential to work with marginalized groups. This means focusing more on the underlying mechanism such as freeing oneself from the white complicities by challenging not only dominant institutions but also rejecting any kind of closed-mindedness and arrogance that academics internalize (c.f., Medina 2013). This is an important task for academics because structural changes can be achieved by cooperating with marginalized groups to develop processes/mechanisms to reflect the way marginalized groups think. From this perspective, authentic pragmatism is the antidote to complicities, arrogance and laziness (driven by the ivory tower mindset and structural biases) (c.f., Medina 2013). For example, often, scholars do not mean what they write or do not act upon what they (publicly) say (see, Perriton and Reynolds 2004). With authentic pragmatism, one should not use marginalized groups or their beliefs strategically to progress one's career or to attain status and reward within an academic community (c.f., Tatli 2012). Rather the focus and energy must be towards the rejection of whiteness and neoliberal mechanisms by collaborating with marginalized groups consistently and in solidarity. Hence, opportunities to show greater resilience towards rejectionist ideas in various forms and manners in accordance with the terms set by marginalized groups emerge. This also means that, in the long run, the language game in which academics (Lyotard 1984) often (un)consciously participate to enable whiteness would be challenged in a more informed way. Once such practices become apparent in the curricula and in how universities disseminate and promote ideas, we will reach the point of decolonizing knowledge in the true rejectionist sense.

CMS scholars must thus ask themselves whether they do research that helps everyone to progress, or whether they only do so to help Western society. After all, most prestigious journals are published in the West-even the journals that promote critical studies. For scientific progress, I contend that such a strategy is not only counterproductive but also unethical. Hence, CMS scholars need to challenge categorization and deeply embedded biases against marginalized groups in an authentically pragmatic manner so that they make a real difference to contemporary societies.

Accordingly, CMS scholars must take Biko's (1972, p. 7) concerns seriously: "So many things are said so often to us, about us and for us but very seldom by us." In this regard, CMS has a moral duty to not only act against racist prejudices in universities but to also forge collaboration among colleagues and with marginalized groups (e.g., by bringing them in and reaching out to them through diverse ways) so that universities promote related concepts such as black feminism (see Hill Collins 2005, 2013) across academic disciplines in order to decolonize spaces. Simply talking about the problem of bias and stigmatization will not help anyone; a pragmatic formula for action must be adopted and mobilized.

Collaboration with marginalized groups does not mean that we always must write about them. For example, for the last five years I have been interacting with a radical activist from whom I learnt how activists differ in their approaches. 
In other words, activism is not just about protesting on the street; rather one can become part of a network where even elites find an activist as a source of valuable information while that activist still disrupts the structure. For example, an activist's information regarding future protest plan or forthcoming litigation charges can influence how a hedge fund would advise its rich/private clients about potential investment in a mining MNC. Again, such precautionary information often forces MNCs to act so that their businesses are not hurt by withdrawal of investment (based on hedge fund's advice to a private client). What this tells us is that not all activists protest through traditional means or media frenzy to glorify their activism. Some want to work in the background and maximize the effect of resistance against MNCs through information exchange with elite actors. This is where working with activists can be interesting as activists are often keen to learn about specific technical knowledge from academics which may help them to improve their activist work. This, for instance, can help activists to play a major role in delisting an MNC from stock exchange or winning litigation against an MNC.

The academic-activist collaboration referred to challenges the way many universities evaluate the research impact of academics. For example, nowadays British universities seek to assess research impacts formally. The problem with such formal assessment, though, is that it may not fully explain how a researcher informally provided strategic ideas to activists to resist an MNC that was involved in forceful acquisition of lands of indigenous people. By not exposing important work of activists in academic journals or formal assessment, researchers can still make a significant impact through their knowledge/wisdom since some researchers have specific knowledge (because of their extensive fieldwork or reading on certain issues) about certain tactics that activists employ.

Nevertheless, researchers must write about their collaborative work to expose the negative behaviors of MNC in every possible way. For example, Fortun (2001) went to Bhopal, India 3 years after the accident in 1984 and lived for 2 years in a house of activists working on social justice and environmental issues. Her collaboration with activists is apparent in her work and demonstrates that researchers can collaborate with activists to ensure justice for marginalized groups and expose any corporate wrongdoing.

More importantly, CMS scholars must continue to critique their own (white) privileges (built into the elite structures wherein they work) and find new ways to avoid negotiations or compromises when writing about and working with marginalized groups (Mignolo 2007; Misoczky 2011). Epistemic disobedience embedded into the rejectionist perspective is not a concept which marginalized groups alone need to act on to develop decolonized space; intellectuals also must fulfill their duties by rescinding the dominant imperialist structure.

\section{Implications for Business Ethics}

I would like to shed light on the effect of moral learning from the RMF movement on business ethics or-more precisely - stakeholder theory. This effect must be linked with Rhodes' activities during his lifetime, which I discussed in an earlier section of this article. Rhodes went to colonize Africa on behalf of the British Empire and, through his exploitative business strategies, was extremely successful. In contemporary Africa, this has two implications. First, it created a legacy from which Africans are still suffering. Their wound is so deep that the pain is still vivid in their souls. Second, unfortunately Africa is still seen as a space where many MNCs tend to operate unethically because of weaker institutions and colonial legacies (see, for example, Ezeudu 2011). In a globalized context, MNCs need to be careful about the way they navigate such geographic locations and the types of legacies they want to (should) leave behind for future generations (Mir et al. 2003). For example, the internationalization strategies that MNCs often use for extractive capital are embedded into the colonial mindset (Cooke 1999, 2003). This raises all kinds of ethical questions about the behavior of MNCs. While the shareholder value perspective may suggest that Africa can be exploited for profit-maximization (as Rhodes once did), MNCs must not exploit resources to maximize shareholder values and propagate the ever-increasing poverty and inequalities in Africa (Idemudia 2009). Rather, MNCs must play a major part in developing ethical and non-colonial spaces, so that ordinary Africans embrace their identity and heritage, show their epistemic disobedience towards MNCs and, more importantly, decide how their resources should be used according to their wishes. If not, in the long run, it is likely that we may see more uprisings such as the RMF movement.

From this perspective, stakeholder theorists must change some of their core assumptions that they refer to when conducting research. Often stakeholder scholars conduct their research by examining value creation in a very limited and superficial way (e.g., Henisz et al. 2014) which influences them to overlook colonial legacies, although in some cases this may be unconscious. It may be true in some contexts, but what really needs to be considered is whether these scholars investigate the historiography of those marginalized stakeholders adversely affected by firms in subtle ways (or who have been adversely affected in the past in ways forgotten by powerful actors). However, stakeholder scholars continue to ignore the evolutionary dynamics of firms and marginalized stakeholder engagement, and subsequently fail to provide a solid perspective on whether firms really take marginalized stakeholders seriously or whether they just 
greenwash everyone to claim value creation for all (Derry 2012; Laufer 2003).

Based on the above, in their research and claims, stakeholder scholars must be sensitive to colonial legacies, historiographies, and contexts in which marginalized groups are embedded, and thus must abandon the epistemic habit of declaring ahistorical and decontextualized approaches to claim neutrality (Jack and Westwood 2006). This is evident in BK's narration where the RMF movement drew criticism from white neoliberal counterparts emphasizing that, if an ahistorical position had been adopted there would have been no need to remove the statue. But BK reminds us that ahistorical and decontextualization approaches are counterproductive for decolonizing space; therefore, I contend that these only delay MNCs' exposure to difficult issues that they initially ignore in the name of instrumental stakeholder engagement.

Ultimately, by taking historiographies and contexts seriously, stakeholder theorists can advance the theory innovatively and open-mindedly (e.g., Lutz 2009), so that it becomes possible to study marginalized groups by accepting that these groups experience whiteness embedded within the existing neoliberal institutions and structures (Dar and Cooke 2008). This in effect can enable firms to find ways to accommodate the rejectionist perspective, rather than seeing such a perspective as a threat to profit-maximization (see, Prasad and Mills 2010). By firms adopting new strategies (c.f., Donaldson and Walsh 2015; Freeman and Gilbert 1992), and by recognizing colonial past, legacies and activities which still persist, it is possible to create greater opportunities for mutual respect and cooperation among various actors, and open up a much-needed conversation that economic means and exploitation are not the only way of doing business in Africa.

\section{Concluding Remarks}

One of the limitations of this article is that it is based on only one interview. Readers may not feel confident about the conclusion I reach based on a single interview (even though I used various secondary sources to conceptualize my work), and some may insist that the article's theoretical contribution is perhaps not strong enough. Nonetheless, this article is not written to simply challenge dominant institutions, but to reject them. In other words, I contend that we must be cautious about the very idea of theoretical contribution as it is often too narrowly defined and articulated, and utilized to misinterpret and misrepresent marginalized groups. Such intentionality and inadequacy then enable powerful actors to impose forceful or violent solutions to what they perceive as the problems of marginalized groups (Dabashi 2015; Spivak 1999). Too much emphasis on illdefined (e.g., skewed towards the significant vantage point of elite actors) theoretical contribution can detract from the stories that marginalized groups wish to tell in their own terms. Under the guise of such theoretical contributions, we must avoid inferring that marginalized groups have nothing new or valuable to tell, simply because they do not have mastery of/over academic language.

After all, some of the problematic normative assumptions of whiteness perpetuated institutionally in management and business ethics studies need to be rejected so as to fight racial oppression and discrimination through intellectual imperialism (Bryant and Tedmanson 2005). From this perspective, I argue that discussion about various aspects of the RMF is more important than claiming a grand theoretical contribution. This does not mean that I encourage anyone to write articles without reasoning, argumentation, and substance (see also, Suddaby 2018). My point is that a powerful story that attempts to capture partial truth is more important than focusing merely on the ill-defined theoretical contributions that we claim through complex models or language games, which in turn retain extreme power/knowledge asymmetries (Bhaskar 1978; Lawson 1997; Lyotard 1984; Ramoglou and Tsang 2016).

Finally, I acknowledge that this article does not discuss intersectional concerns, patriarchy, or sexual violence, which BK highlighted in his interview. All are important topics in their own rights (see, for example, Hill Collins 1990, 2005; Hill Collins and Bilge 2016). However, this article provides an opportunity for future research to explore how such issues arise in the movements, mechanisms and processes that marginalized groups utilize to eliminate and fight such concerns within and outside movements and daily struggles. By doing so, future studies can focus more on the structural conditions under which violence-for example, sexual harassmentarises and explore in greater detail how that can be fought, for instance by incorporating black pain and the rejectionist perspective. While this line of inquiry can equally enrich CMS and business ethics scholarship by focusing on the struggles of black female counterparts, this type of research becomes most pressing as Chumani Maxwele (cited in Stiem 2018) rightly stated when he splashed a bucket of human waste over the white supremacist Rhodes's statue: "There is no collective history here-where are our heroes and ancestors?"

Acknowledgements I sincerely thank the associate editor, Sara Louise Muhr, as well as three anonymous reviewers for their guidance in improving this article. I would like to give special thanks to Gregory Hood, Penelope Muzanenhamo and Benjamin Siedler for their careful review of my work. I also thank Alessio Cozzolino and Gerardine Doyle for their helpful comments on earlier versions of this article.

Funding I acknowledge the support of AESOP+ (funded with support from the European Commission) to attend University of the Western Cape as a visiting scholar and University of College Dublin's partial funding for this research. 


\section{Compliance with Ethical Standards}

Conflict of interest I declare that I have no conflict of interest.

Informed Consent Obtained (the respondent agreed to reveal his name for this article. Also, note that the final version of the transcription was shown to the participant for approval so as to avoid misrepresentation). All procedures performed in studies involving human participants were in accordance with the ethical standards of the institutional and/ or national research committee and with the 1964 Helsinki declaration and its later amendments or comparable ethical standards.

Open Access This article is distributed under the terms of the Creative Commons Attribution 4.0 International License (http://creativeco mmons.org/licenses/by/4.0/), which permits unrestricted use, distribution, and reproduction in any medium, provided you give appropriate credit to the original author(s) and the source, provide a link to the Creative Commons license, and indicate if changes were made.

\section{Appendix: Interview with Brian Kamanzi}

Interviewer How did the Rhodes Must Fall (RMF) movement begin?

BK: Initially, there was a group of protestors, including Chumani Maxwele, and they were protesting at the site of the statue. Chumani brought feces with him from Khayelisha, a township about 20 min away, and threw it on the statue. He was making a statement about the realities of life in the townships compared to the opulence of Cape Town. He was saying that Rhodes' vision is embodied by what the University of Cape Town (UCT) is: This is the filth that people must live in and endure. There was a huge uproar at the university in response to Maxwele's act in March 2015.

There were three main groups comprising political parties, student societies, and non-aligned independent students. They combined under a Broad Church agreement understood as the principles of pan-Africanism, black radical feminism, and black consciousness. You could say these three pillars were embodied in groups prior to this, although they were not always clearly represented, and the various groups or camps were often antagonistic to one another. However, now that the groups were coming together, there was a lot of backlash from conservative whites who called this mobilization "barbaric." It was becoming clearer by the day whose side you were on. From that, and based on a couple of public dialogs, students decided to turn this moment into an actual social movement that resulted in a few marches. There was an occupation in the admin building called Bremner (at UCT), which probably solidified and characterized certain elements of the movement. At first, there was no hierarchical framework, so decisions were made in a plenary session by achieving consensus. Second, the method of occupation was central to the conceptualization of the politics. This also represented the space in which the thrust for decolonization was acknowledged - and identified as encompassing those three pillars.

Interviewer Who played key roles in mobilizing the RMF movement?

BK Many people. I do not know if I can list all of them, but they included Ru Slayen, Leila Khan, Kealeboga Mase Ramaru, Masixole Mlandu, and Lufefe Malala. They were there from the beginning. Everyone who was in the movement came from UCT.

Interviewer Did they know each other?

BK Maybe; if they did not know each other beforehand, they probably shared mutual contacts. It was a fairly apathetic space before the movement and then things started to heat up on campus, certainly in terms of dialog, so people who had views were more or less aware of each other's existence and even facilitated that kind of political collaboration in the first place. Also, I think there were groups like Palestinian Solidarity Fund, Worker Left Form, Left Students Forum, and 'Imbizo' which was related to a youth group of the pan-Africanist Congress called PASMA, and they had already been running dialog sessions at one of the residences. I think a lot of the popular education at the time was facilitated through such mass participation with these groups and others such as, for example, the South African feminist group, which had a very large constituency then.

Interviewer What was your role in that movement?

BK The model was all about self-participation; you decide what work you want to do. In hindsight, my role now links more into the education subcommittee. A lot of the work in RMF is not about protest; it's more about educational material. In the beginning, I was involved in identifying speakers and curating the spaces in which we would hold seminars. Our methodology included disrupting lecture spaces; we avoided holding our events at elite venues and even tried temporarily occupying spaces such as reception areas by having reading groups there, for instance. At that time, there was a lot of energy. Many people wanted to speak to us. We had the luxury of thinking creatively because there were so many resources being thrown at us.

Interviewer How did activists mobilize the movement? Can you discuss more about protest, organizations, and the subcommittees you mentioned? What kind of structure did you have or how did you come to occupy reception areas?

BK Basically, we would call a plenary session at, say, 6 o'clock. However, we had a watershed moment: The first occupation might involve 3 or 4 days where no white participation was allowed, only blacks, in the broad definition of black. You are welcome to attend and you attend the plenary space. An agenda is drawn up, either from the minutes of the previous meeting or from people in the space who want to discuss specific issues. Then we report on outstanding tasks and remaining issues are raised. When an issue is raised, 
a team is appointed to resolve it. For instance, there might be a rugby match taking place tomorrow and we consider whether to disrupt it. There were actually two occasions when such disruption happened. In situations like that, you ask what is required for action: Do we have a radical action team already? Is it functional? If not, reconstitute it. It's a voluntary process. You identify members who are willing to take a role and then disruption takes place. Afterward, these volunteers report on how things went, and they announce when the next set of actions are. To be honest, this did not always work well, despite our open-door policy. The work is voluntary, so we can only confront as many issues as people volunteer for. Moreover, accountability was difficult because we did not have a membership system, so we couldn't do just anything. When emotions were running high and we had public sympathy on our side, it was easier and people were more willing to give their best, but at later stages and phases of the movement this was not the case.

Interviewer Can you narrate the mobilization process chronologically?

BK As I recall, the feces throwing happened March 9, and an occupation took place March 21. It was massive; thousands of people came to UCT every day. It came to an end around the second week of April when the university served a court order (issued by Wynberg Magistrates Court) and we were evicted. Another occupation took place a few days later at the housing administration office in protest against dispossession. It was about the state of land reform in South Africa and also noted that the movement itself needed space to operate. At that time, sympathy was low because the university succeeded in convincing the public that our demand was essentially about bringing down the statue and pretended not to be aware of our other demands when, actually, we had presented the university administration with an extensive list of broad-ranging issues from basic minimum wages for the workers to curriculum issues emphasizing subaltern-centric Africa. But their propaganda was successful when the statue was removed. Everyone was saying to the students, "Why are you still in the occupation?" It took a while to make people understand why we were still occupying.

The second occupation occurred between June and July, as I recall, and was at a place called Avenue House at UCT, resulting in several charges. The building was used as a student accommodation office and part of the point we were making was to continue our insurrectionary position on "land" and, therefore, housing by occupying this space both for its symbolic value in highlighting the systematic exclusion of black people in general from these institutions and the pragmatic need to have a space in which to meet consistently and continue the project we had embarked upon. We had to carry it through a mediation process which took us into August 2015. There was a vacation period between early June and late July. In early August, when the disciplinary charges for all prior protest action (such as trespassing during occupation) were lifted, we successfully navigated through the mediation process which was conducted by representatives of the movement and the Senior Management Team of the university. The appointed mediators were Stanley Henkeman and Tim Murithi from the Institute for Justice and Reconciliation. Then we started trying to re-establish participant numbers. During that time, we planned two landmarks occasions, one being the anniversary of Marikana and the other involved efforts to resolve the issue of outsourcing. This referred to a policy that transferred low-wage service jobs out of direct university employment to external employment agencies, often resulting in even lower wages and considerably fewer social security benefits. Thus, through our politics, we conceptualized the anti-privatization struggle as being "un-colonial." For us, social justice is more complicated than Marxist ideology simply in direct confrontation with other ideals. On August 16, we had some public art for Marikana. We tried to connect with the workers. We tried to rename Jameson Hall as Marikana Memorial Hall to make a point.

Here, I think it's worthwhile mentioning that the commissioner of the Marikana Commission, Ian Farlam, is on the UCT council. We found that about ZAR $2 \mathrm{M}$ of UCT staff annuities had been invested in Lonmin, the mining company implicated in the Marikana massacre, and we wanted to call Farlam's neutrality into question by highlighting that he would almost certainly have been aware of this financial arrangement. Therefore, he should not have been allowed to participate in the case because there would be a conflict of interest. It didn't work, and Farlam's position was nevercontested within the council body. But it was an interesting attempt that helped our effort to conscientize and bring to the fore workers' issues both nationally and on our campus, in the context of colonialism, helping us to change the public perception of us that, somehow, everything was about the Rhodes statue.

In late September, we started planning a documentary, "Outsourced," which you can check out on our UCT page. We were trying to highlight the plight of outsourced workers and their working conditions. This led up to the first national protest, called "October-6." It involved us, Wits University, and a couple of other universities. Together, we had built solidarity from the early RMF days. Shortly afterward, a call for free education was made from Wits University. When that call was made, and in light of the established networks and the success of the October- 6 campus shutdown (conducted largely by students and some workers), it created a situation in which we were prepared to say, "Yes, definitely, that is within the scope of our politics. We support the objective of Free Education." That was the time when Fees Must Fall became a national project and RMF participated in that 
and campus shutdowns. I contend that UCT students instrumentalized the work. Now, the Fees Must Fall project at UCT housed our third occupation in Avenue Hall, adjacent to Avenue House I mentioned earlier. But we were evicted, so we moved next door and established a central operating space for our movement and for Fees Must Fall. We managed to win the battle of outsourcing within a couple of days. Then, an agreement was reached between UCT and the labor union. That union wasn't even driving the Fees Must Fall and End Outsourcing strike; it was affiliated to the African National Congress (ANC) and was uncomfortable with the students' ideological line, particularly after the protests started to be directed at the state. Hence, we decided to assemble at parliament and another mobilization happened at union buildings. The students, who were protesting there for the first time, pushed through the gates. It was the first time in democratic South Africa that police repelled the students with stun grenades. The ruling party demanded that the labor unions, i.e., the allied movement, cut their connection with students. Also, the students were divided when the president announced a $0 \%$ fee increase. Actually, it wasn't one of our demands but, at that time, many people were satisfied with that. Moreover, many people didn't conceptualize the struggle clearly because the movement itself was vague and inconsistent about what exactly "Free Education" stood for. Many people felt that the state's decision to cover the 2016 fee increases was a show of good faith and was grounds enough to break the strike, but this was fiercely contested internally. Essentially, certain groups were alienated because of that and RMF was crushed by disciplinary charges and internal splintering, being dragged in and out of court.

The following year saw an onslaught of propaganda which led to disintegration and poor discipline within the movement. We also struggled with the patriarchy in the movement space; there were many instances of sexual violence. Internally, things were not handled competently and, hence, both our internal and external credibility really suffered.

On February 16 and 17, 2016, there was a student protest called "Shackville," in which a shack was erected on the campus as protest art in opposition to housing and academic exclusions. We never intended to protest against housing in 2016, but many of our members were kicked out in various ways because of housing inefficiency at the university. We discovered that first-year students had been turned away from the residences despite the fact that they had their acceptance letters. The reason was that UCT was oversubscribed; they had anticipated that students would not accept their offers. But it worked on a first-come, first-served basis, so when wealthier students first arrived, presumably due to their access to transportation, they secured the first spaces in the residences. As a result, the university management established a team to address this issue. But we refused to speak to the team; we wanted to speak directly to the Vice
Chancellor. They told us that because were being disruptive we must move the shack onto the grass. Eventually, all this turned into a riot where the paintings were burned and a car, a bus, and the Vice Chancellor's office were petrol bombed. I'm not sure that we were responsible for burning the vehicles, because this wasn't really characteristic of our movement-we had been striking peacefully for almost a year-so there's a possibility that agents provocateurs were involved. Other, disenfranchised people with nothing to lose may also have been involved; occupying the same space as us, their lives had been essentially ruined, having been financially excluded from the institution. Therefore, we were criticized for not condemning the violence. Our reasoning was that that, yes, it could be agents provocateurs and/or it could be poor students, and we would gain nothing by condemning them. It would be self-indulgent, if anything. Consequently, the UCT authorities used that opportunity to identify people who they perceived to be ring leaders and bar them from attending campus. Unfortunately, I was in that group. They later withdraw most of their accusations because they didn't have any evidence against us, however they are still pursuing five of the students to obtain a final interdict, which would concretize the restrictions made in the aforementioned court order, and that's where we are now.

Interviewer What is black pain? What's the significance of this phenomenon?

BK It relates to setting up an antithetical argument and resolution of the master-slave dynamic. It says that South Africa was constituted through colonialism. Colonialism was deigned to maintain white supremacy and the hierarchy of racism. "Humanity" was benchmarked then by the white male, hence the "universal" and "objective" standpoint was European. "Inhumanity" is, thus, embodied by blackness, and black pain is the psychological and physical experience of having to live as a human who is subject to inhumanity. On one hand, you have the psychological trauma of experiencing white supremacy in age of neo-liberalism; on the other, racism exists but, by white definitions, without racists. You can see here all the elements of white supremacy in the context of UCT - not that different to 30 years ago. However, people with clever language can now evade responsibility for what is very clearly a problematic and racist society.

Interviewer How was black pain mobilized during the movement?

BK Rhodes was used emotively as representing the root of the matter, his legacy being the colonial experience for black people in South Africa, and that the black pain you are experiencing here is a direct result of colonial conquest. So, you could say the psychological remedy for the pain is decolonization-hence, the removal of the statue. Perhaps it should have been the destruction of the Rhodes statue; a catharsis to the subjugation of Rhodes' project. This would 
create space for something else to develop and for people to live

Interviewer Did RMF only attract black students and communities or was there wider support for the movement in South Africa?

BK I think there was criticism against the movement from all sides. In the beginning, there was a lot more interest and support from black South Africans, although now the people most interested in RMF are white South Africans. They are obsessed with the space where they can commune to provide support and resources. Others would follow everything and comment on everything; perhaps they feel psychological guilt about the conversations taking place or fear that, somehow, we'll ransack their homes or whatever. Moreover, I think that, recently, there has been significant tension brewing between younger South Africans and the older generation because the older generation is saying, "You guys are disrespectful" whilst the younger generation is saying, often without fully appreciating what happened, "They sold out." Opinion is divided on the notion and role of "respect" and so support for the movement has definitely been skewed as a result

Interviewer How did the UCT authorities react to the movement's demands?

BK I think a lot of university executives were probably sympathetic to our ideas. However, they tried to control the situation. Ultimately, it's going to cause disintegration of the space. It was clear that a lot of the administration (even some of the white academics, although they won't admit it) didn't understand the intellectual questions raised by decolonization and what it is that we are asking for. They tried to convert all our demands into some kind of tangible desire- - the statue being one of them-to work out how to appease these angry students: "If we just remove the statue, hopefully the aggrieved students will be fine." They just weren't getting it. There were fairly complex existential arguments about space, the nature of the curriculum, and the role of the university. It was a "Can the subaltern speak, now?" moment; we felt we were saying many sensible, complex things but nobody was listening to whatwe said or reading what we wrote (through statements) in the public space. Everybody was justanalyzing our actions. Even academics, when they speak about us, don't refer to our statements which are often lengthier than their articles. So, I think that, although RMF has many revolutionary objectives-it has been a fairly bourgeois movement-it will only be with the benefit of hindsight that people will understand what it was that RMF was actually asking for

Interviewer As you suggest that they tried to control the movement, did they use violence, or was it just rhetorical?

BK In the beginning, it was rhetorical on both sides. However, since the Fees Must Fall movement, it got violent. I think as soon as the labor questions were connected it became a different ball game because now you're dealing with serious numbers of people and, inevitably, if it involves both students and workers then there's likely to be violence

Interviewer What kind of violence did UCT use?

BK UCT actually had a policy during apartheid that they would never bring police into the campus. That was their commitment. It was broken on October 20, 2015, I think, with us. They brought police into the campus and evicted students. It spiraled into a situation where police were just there to pick up students. There was a lot of fighting: Police coming in with stun grenades and targeting students. Consequently, there was a backlash against the police during November 2015. After that, UCT hired private security. During exams, UCT hired a company called Vetus Schola, which was also doing work at University of Western Cape. This company was much more violent than the police. You could see that the strategy of how to deal with the protests had been conceived at Wits and at UCT and instrumentalized at the other campuses, University of Western Cape being one of them. When it is instrumentalized, it gets worse; you see the uglier elements at the universities that have more working-class people. UCT had the lighter, "civilized" version of what would be happening elsewhere in South Africa. Private security firms came in and UCT paid them ZAR $2 \mathrm{M}$ per month. Their personnel can be pretty messed up, as some of them have said openly. A couple of them had been white mercenaries and spoke about having fought in Angola-a crazy situation with provocations left, right, and center. The university's own security service wouldn't touch the students because a good relationship had been established during previous solidarity efforts. They had, so to speak, been turned. Thus, UCT had to bring in an objective, third-party provider that had nothing to gain from the struggles on the campus, making it easier for them to exercise the necessary repressive force

Interviewer So, until now, security is enforced privately. How did the South African government respond to the movement?

BK Initially, they kind of ignored us. I think we were safe for a while because, in April 2015 when the movement was big, a lot of the politicians tried to affiliate with the movement; except the ANC. There were many others who tried to attend to show face, as if they were part of the movement. We rejected them because the movement is a non-partisan movement; we're not interested in political games. We were safe in the beginning because we were targeting white liberalism, where our critique is strongest. Actually, we were unprepared during the fees protest to confront the state; our thesis was very centered and anchored on the white administration and peculiarities of UCT. Hence, the state was antagonistic toward us. At the same time, they described our activities as "violent." They remain quite concerned-we have been pushing for decolonization—and I think they're 
seeking to frame us as a terrorist organization. It's no different from what's happening at Jawaharlal Nehru University in India; what we're saying is sedition because we are in a sense insisting that we are in a false democracy. We are joining others who suggest South Africa should participate in a revolutionary process and that there must be a radical redistribution of wealth

Interviewer Do you see the movement as a success?

BK I think it's too early to tell. Probably not. I think it created fertile ground for new possibilities in South Africa. I think it is the most sensible way of looking at what we always were. It may give rise to other movements. I think it has raised good questions about how we should move forward, even as individuals. Nonetheless, I think the movement itself is struggling. As we saw at the exhibition, 1 year later, on March 92016 (http://www.iol.co.za/news/south -africa/western-cape/trans-collective-trashes-rmf-exhibition -1996847), with our conceptualization of the problem from the perspective of RMF and the opposition students' concerns about intersectional identity/rights and the possibility of waging an intersectional struggle, it was something we failed to uphold ourselves, and that led to the disruption of the exhibition

Interviewer How do you see the media's portrayal of this movement, both in South Africa and the West?

BK Problematic. Especially the way in which it focused on individuals in the space in general and, unfortunately, on men in particular. I can recall many instances with the local media where they wanted to get statements. They asked whether we had a spokesperson. When we said no, they would identify whoever was speaking as a spokesperson because they were just not willing to accept our way of organizing and expressing ourselves. They were trying to force structure upon us-in the same way that society itself is structured. For example, society prefers to see male leaders. Media gravitates toward the men to speak by quoting or emailing them for an interview whilst ignoring women or transgender people in the space who are raising intellectual questions. Decolonization becomes associated primarily with some random guy who is chanting "Kill all whites" instead of the 30 or 40 points that were raised by the transgender women. Why does the media choose to go to with the random guy in this case? I have no doubt that there is no such thing as media objectivity. Maybe, for a couple of the South African media houses, we have been the goose that lays golden eggs in that people want to read what is happening, but they sensationalize a lot of stuff and they take things out of context. I have also been disappointed with the international media because they do not reference sites in which the movement articulates itself. They give a sense that they are objective, third-party observers, which means or speaks to the pedagogy of what is happening more broadly in South Africa, whereas they could actually concentrate on our writings and see the central question or refer to the first set of demands we have rather than portraying that the movement is all about the statue. Why don't the media see that the students' demands are about more than just a statue! I think there is extreme arrogance in their reporting; they just write about it as if they're simply not interested in reporting the actual matter. This is a debate about media responsibility

Interviewer How can removal of a statue, which is a symbolic object, help in the fight against white supremacy?

BK I think it is about epistemic disobedience. It's about undermining the entire project of UCT. This is important to contextualize because, often, when people say they know how to remove a statue-they have to consider all the elements leading to that decision. That call is made in a space which essentially glorifies this man in direct and indirect ways. Hence, attacking the statue was doing exactly the opposite

Everybody was questioning the point of removing a statue. They were not just saying what is the point of removing it, they were saying, "No, don't touch it. It does not mean anything to remove it." But, clearly, it does. There is a reason why those statues are built in such a way that it's difficult to pull them down. I think statues in that era were built with the understanding that the political climate would change and they believed that they would outlive the world, like some maniacal fantasy. They believed that we would defy at some point. I don't necessarily believe that destruction of artifacts is the way to achieve a [social] change. However, I think that these kinds of things are a manifestation of change itself and the removal of a statue provided us with a strategic device which, in effect, enabled us to articulate many issues that meant different things to different people. In the idea of removing the Rhodes statue, people saw their own meanings expressed through different emphases, for example how gender is constructed in colonial reality, or how migrant labor and capitalism functioned. It was a good learning device for many issues and I feel that we all learned a lot from this exercise. Also, in South Africa, history is not a widely taught subject. For example, during my high school years, they stopped offering history. After Grade 9, even if you wanted to take history as a subject, they stopped offering it up to the matriculation level [Grade 10] because nobody was talking about it. They wanted to emphasize the math and science because a high-skill economy needs engineers and doctors. I think that there is something to be said here about a movement_-youth movements_asking particular questionsabout history because we are a fairly uninformed society when it comes to our own history. I think persistent inquiry into the past is necessary so that we don't repeat our mistakes

Interviewer Some have argued that Rhodes made a significant contribution to society. Because of his donation to the universities such as Oxford and UCT, these universities 
are improving their education systems and spreading equality and justice all over the world. For example, the Rhodes scholarship is quite famous, one that Bill Clinton for instance achieved...how do you respond to your critics?

BK I think that education should be free. I think the fact that there are scholarships is an aberration. I think that they contribute to uneven distribution of political and social power. The Rhodes scholarship is actually one of the finest examples of that. It is complicit in producing global elites within the Third World who hold a monopoly on knowledge. It also gives elites access to governmental power. It is like a rubber stamp for life that you are going to be an important person as a Rhodes Scholar. Of course, it's a certain kind of Third World hook for whoever manages to make his way through. Similarly, I think Rhodes' legacy permanently damages physically and epistemologically the space in which he operated and overcame, so to say that he contributed to equality is backwards. In fact, we have to do the equality work. We have to repair what he has done in the space. We cannot be penalized and we do not have to thank Rhodes for the skeletons of his project that he left behind for us to reconstruct our society. People say that he "donated" the land. But if you call into question the very notion of "private" when describing the principle of property in our society, then how can you credit him for donating that which he should have never taken? If you look at the university infrastructure itself, an important question arises: Who built the university? In fact, Rhodes is quoted as saying that he built the university out of the "stomachs of kaffirs," one of the most vicious and derogatory phrases to describe black people in our context. It was black workers who built the university. Who owns the product and the labor? For sure, Rhodes did not pull those stones up the steps that I walk on. He may have provided certain ideological boundaries or tools with his architects, but it was the laborers who at the end of the day played the most significant role in creating that space. I think that it is precisely these reasons that we are able to embody those works and give them different kinds of meaning. It's not necessary that we have more universities like UCT to have an equal society; UCT could burn down tomorrow and we could still have an unequal society. It's a similar thing with the Rhodes scholarship; we don't need the Rhodes scholarship to have a more equal education system. There are many other ways to achieve that. It's backwards to say that Rhodes' contribution-the emphasis here is in particular on what has been done to the colony-has to be weighed against his imperial legacy: His contribution to creating things like race in particular and the differentiation in class is irrecoverable. The benefits of any society belong to those who struggle for it and not those who act against it

Interviewer Why do you think that students in the UK and activists have failed to make the authorities remove the statue in Oxford?
BK Part of the problem I think is that they held the South African movements at arm's length. Our movement was promoted by occupation. Collaboratively, there could have been various debates around strategy that could have taken place across our contexts, but to my knowledge we didn't make it happen. I think the questions about expectations of solidarity link to how each group had different objectives and, thus, they conceptualized the struggle differently. All fair and fine. But, on our side, the statue was removed and the other changes that we achieved because of radical actions at various levels and direct actions together formed a part of that. The differences in the ways risks were taken in our context is stark and I think that has to really factor into what we think it would take to break the epistemic foundations of privilege that embody a place like Oxford. From a distance, it makes me wonder what other local forces and/or communities would have been crucial to making "decolonization" the dangerous call it could be at institutions like Oxford

Interviewer From your experience, are violent or nonviolent protests more effective?

BK It's tricky toanswer because of how we choose to understand violence. I think that protests are always violent. If they are not violent, then they are not protest. It's either epistemologically violent, or physical violence, or both. I don't have a particular desire for physical violence. However, where I am now, I see it being permissible as it is reactionary or it is self-defense. Yes, many paintings were burned, however from what I witnessed, it's neither "good" nor "bad." It simply is, i.e., when people are frustrated and you have a chaotic situation, it serves no one to say whether they are good or bad and it often ignores the, often structural, violence that led to that particular flare up in the first place. I think that in a mass protest and an armed struggle, both violence and non-violence have their uses, and they must be decided upon, with their attendant consequences, by those who are resisting. Anyone who believes in a modern democracy is far from being a pacifist because they are saying that violence is permissible, but the state has a monopoly on violence and that's how you permit a police service, an armed force and, now, private security forces. I think that people who have different versions of justice but who are not pacifist have a similar view that violence has a particular political utility and therefore can be used to implement their form of justice; but this really deserves a longer, separate discussion

Interviewer How do you see the legacy of Nelson Mandela who was in favor of non-violence in post-apartheid South Africa?

BK Well, I think that it is not true that he was in favor of non-violence for two reasons. He was part of Umkhonto we Sizwe and he was part of the operations. I mean, he was a terrorist on the CIA list for a long time, even during his presidency. Again, in a similar comment that I made 
about pacifism, he was the president of a modern democracy. He simply believed that the state has a monopoly on violence, that's all. I don't believe that there has ever been a president of a state that has ever supported nonviolence. I think that Nelson Mandela's legacy on nonviolence should be seen as part of the capitulation of the pursuit of the armed struggle alongside the impossibility of continuing apartheid in its brute and crude form due to international pressure for reform. I think that, to some degree, political power was transferred and power sharing took place, and that's what Nelson Mandela was a part of. It's an incredibly compromised, complex legacy that is going to mean different things at different times, but something that has unfortunately become crystalized within the name of an individual. There are a lot of young people looking at him very critically now in comparison to maybe 5 or 10 years ago

Interviewer And they have a different kind of understanding of Nelson Mandela?

BK I would say Nelson Mandela is an abstract, because he has reached a sort of divinity in public discourse. But he sits on two planes. People have distinct views of Nelson Mandela the icon: Either for or against

Interviewer Why didn't the black communities in South Africa flourish after the end of apartheid, given that the ANC and the anti-apartheid party was in power for more than two decades?

BK It's about the negotiated settlement and the conditions required for flourishing. In a situation where the majority of the economy is still owned by white South Africans and where the Truth and Reconciliation Commission process was not fully implemented, those people didn't come to deliver testimony. In fact, a large proportion of white South Africans claim not to have understood what was taking place. You have a situation where forgiveness was given prematurely. There is no radical plan for the redistribution of land. There is willing buyer/willing seller which has proven to fail. South Africa isn't quite an egalitarian society or hasn't made firm decisions whether it wants to be. I think that the conditions for flourishing were difficult to create and that is also seen in the structural adjustment plans of the 1980s throughout the continent. Is it a reasonable question to ask why Africa is not flourishing, given that it was set up to fail more than three decades ago? As far as individual decisions are concerned, we made mistakes: We sold our pre- and post-apartheid parastatals and sections of the economy to the West and, more recently, to China. The growth of the black middle class that has accompanied the capture of some degree of political power cannot be ignored and has its consequences for what sort of progressive changes and politics we might conceive in the future; this is an aspect I don't think the student movement considered clearly enough, even at an ideological level—after all, many of us are from that class! We are also struggling to pay off loans, loans that we're unlikely ever to be able to repay. I think it's a fundamental element of the global economy that the Third World will remain as it is. Nevertheless, what I do think is that we missed an opportunity to codify certain principles of our society and, for me, I think that the next stage of our democracy is to fight for specific principles and attain them. For example, free education would be one of them because we are in a highly constrained environment. Also, we will never be able to compete through military might with the West, so we will have to identify ways for social protection for our citizens or call into question the very notion of citizenship itself

Interviewer Are there any other issues that we should discuss, which you think are important to tell the world in terms of representation?

BK Perhaps I failed to emphasize the importance of the black feminist section of our movement and how they were central in posing interesting questions around decolonization and the future of these kinds of movement. The previous decolonization lobby pushed for independence but they didn't really pay attention to this issue enough or they silenced the voices in their movement to the point where it was not addressed. Unanswered questions, then, include what a feminist state looks like, and whether direct action is imbued with patriarchal elements or ways of constructing power. It may be less interesting to some of my other comrades, but what I would like to emphasize about RMF is that it tries very hard to be decentralized and so it means a variety of things to different people. This is both its strength and its weakness. This may not be fully understood in our time, which is fine, because there are moments which are catalytic and, when the dust settles, we try to figure out what happened. I am not entirely sure myself what happened here, but what I am sure of is that change is coming in South Africa and it's a good sign that the youth are willing to fight for it

Interviewer You mentioned earlier, sexual violence against some students; who was responsible for that?

BK In some cases, it would be members of our movement and, in other cases, it would be newcomers-because its membership is fluid-but I think you often have this in social movements where sexually assaulting, harassing happens

Interviewer Was any action taken against the people involved?

BK There were actions taken, driven especially by the women in the space. I think that a lot of efforts tried to emphasize the educational element that people must educate themselves. I think, over time, frustrations grew. I think it's just a conundrum of how do you respond, and who responds? Because, on one level, you also know that if people go to jail, no one is going to be reformed there; it's a terrible place. 
However, whose needs are we prioritizing when we consider that? What about the victim? It's complex and we failed, particularly the men in the space, to rise to that complexity. You know, jail is not a restorative, reparative space, so the question of how to deal with it is still unclear. If that kind of behavior is allowed to flourish, then what South Africa needs is an independent, mass feminist movement that could be in solidarity with other kinds of struggles; for example, it could be a united front against some other issue. That would be more sensible because South Africa is one of those countries with high levels of gender-based violence, so feminism deserves to be at the forefront and not an element of another movement-it's a legitimate issue on its own

Interviewer Thank you very much

\section{References}

Adell, S. (1994). Double-consciousness/double bind: Theoretical issues in twentieth-century black literature. Urbana: Illinois University Press.

Ahman, S., Fine, B., \& Newman, S. (2011). The crisis in South Africa: Neoliberalism, financialization and uneven and combined development. Socialist Register, 47, 174-195.

Allen, T. W. (1994). The invention of the white race. London: Verso.

Beckert, S. (2014). Empire of cotton: A global history. New York: Knopf Doubleday Publishing Group.

Bell, E., \& de Gama, N. (2018). Taking a stand: The embodied, enacted and emplaced work of relational critique. Organization. https:// doi.org/10.1177/1350508418815424.

Bell, E., \& King, D. (2010). The elephant in the room: Critical management studies conferences as a site of body pedagogics. Management Learning, 41(4), 429-442.

Bell, E., Meriläinen, S., Taylor, S., \& Tienari, J. (2015). An ethic of care within critical management studies? In A. Prasad, P. Prasad, A. Mills, et al. (Eds.), The Routledge companion to critical management studies (pp. 56-68). Abingdon: Routledge.

Bhaskar, R. (1978). A realist theory of science. Hassocks: Harvester Press.

Biko, B. S. (Ed.). (1972). Black viewpoint. Durban: SPRO-CAS Black Community Programmes.

Bryant, L., \& Tedmanson, D. (2005). Drilling down: Diversity in the mining industry. International Journal of Knowledge, Culture and Change Management, 5(3), 157-168.

Burrell, G., \& Morgan, G. (1979). Sociological paradigms and organizational analysis. Ashgate: Burlington.

Chaudhury, A. (2016). The real meaning of Rhodes Must Fall. The Guardian March 16.

Chowdhury, R. (2017). The Rana Plaza disaster and the complicit behavior of elite NGOs. Organization, 24(6), 938-949.

Chowdhury, R., Banerjee, S., \& Nagarkoti, D. S. (2017). Anna Hazare: A corruption crusader and his grassroots wisdom. Journal of Management Inquiry, 26(4), 383-389.

Chowdhury, R. (2019). (In)sensitive violence, development, and the smell of the soil: Strategic decision-making of what? Human Relations. https://doi.org/10.1177/0018726719874863.

Chowdhury, R., \& Willmott, H. (2018). Microcredit, the corporatization of NGOs and academic activism: The example of Professor Anu Muhammad. Organization, 26(1), 122-140.

Connell, R. (2007). Southern theory: The global dynamics of knowledge in social science. Cambridge: Polity Press.
Cooke, B. (2003). The denial of slavery in management studies. Journal of Management Studies, 40(1), 895-1918.

Cruz, J. (2014). Memories of trauma and organizing: Market women's susu groups in postconflict Liberia. Organization, 21(4), $447-462$.

Dabashi, H. (2011). Brown skin, white masks. London: Pluto Press.

Dabashi, H. (2015). Can non-Europeans think. New York: Zed Books.

Dar, S., \& Cooke, B. (2008). The new development management: Critiquing the dual modernization. London: Zed Books.

Daskalaki, M., \& Kokkinidis, G. (2017). Organizing solidarity initiatives: A socio-spatial conceptualization of resistance. Organization Studies, 38(9), 1303-1325.

den Hond, F., \& de Bakker, F. G. A. (2007). Ideologically motivated activism: How activists groups influence corporate social change activities. Academy of Management Review, 32, 901-924.

Derry, R. (2012). Reclaiming marginalized stakeholders. Journal of Business Ethics, 111, 253-263.

Donaldson, T., \& Preston, L. E. (1995). The stakeholder theory of the corporation: Concepts, evidence, and implications. Academy of Management Review, 20, 65-91.

Donaldson, T., \& Walsh, J. P. (2015). Toward a theory of business. Research in Organizational Behavior, 35, 181-207.

Du Bois, W. E. B. (1903). The souls of black folk. New York: Bantam Classic.

Du Bois, W. E. B. (1920). Darkwater: Voices from within the veil. New York: Washington Square Press.

Du Roy, I. (2013). Remembering French Investments In Apartheid South Africa. South African History Online. Retrieved from https://www.sahistory.org.za/archive/remembering-frenc h-investments-apartheid-south-africa-17-december-2013. Accessed 3 Jan 2018.

Eesley, C., \& Lenox, M. J. (2006). Firm responses to secondary stakeholder action. Strategic Management Journal, 27, 765-781.

Ehrnström-Fuentes, M. (2016). Delinking legitimacies: A pluriversal perspective on political CSR. Journal of Management Studies, 53(3), 433-462.

Ellwood, W. (2004). The no-nonsense guide to globalization. Oxford: New Internationalist Publications in association with Verso.

Ezeudu, M. (2011). Revisiting corporate violations of human rights in Nigeria's Niger Delta region: Canvassing the potential role of the International Criminal Court. African Human Rights Law Journal, 11(1), 23-56.

Fairbanks, E. (2015). Why South African students have turned on their parents' generation. The Guardian November 18.

Fanon, F. (1961). The wretched of the earth. New York: Grove Press.

Fanon, F. (1967). Black skin, White Maska. New York: Grove Press.

Fortun, K. (2001). Advocacy after Bhopal: Environmentalism, disaster, new global orders. Chicago: University of Chicago Press.

Frankenberger, R. (1997). Displacing whiteness. London: Duke.

Freeman, R. E. (1984). Strategic management: A stakeholder approach. Boston, MA: Pitman.

Freeman, R. E., \& Gilbert, D. R. (1992). Business, ethics and society: A critical agenda. Business \& Society, 31(1), 9-17.

Frooman, J. (1999). Stakeholder influence strategies. Academy of Management Review, 24, 191-205.

Gasa, S., \& Dougan, L. (2016). Fees must fall 2016: Where to from here? GroundUp October 4.

Gilroy, P. (1993). The black atlantic: Modernity and double consciousness. Harvard: Harvard University Press.

Girei, E. (2017). Decolonising management knowledge: A reflexive journey as practitioner and researcher in Uganda. Management Learning, 48, 453-470.

Graeber, D. (2004). The new anarchists. In T. Mertes (Ed.), A movement of movements. Is another world really possible? (pp. 202 215). London: Verso. 
Gramsci, A. (1971). Selections from the prison notebooks. London: Lawrence and Wishart.

Guha, R. (2002). History at the Limit of World-History. Columbia University Press.

Hahn, S. (2005). A nation under our feet: Black political struggles in the rural south from slavery to the great migration. Cambridge, MA: Harvard University Press.

Hamer, J. F., \& Lang, C. (2015). Race, structural violence, and the neoliberal university: The challenges of inhabitation. Critical Sociology, 41(6), 897-912.

Harding, A. (2015). Cecil Rhodes monument: A necessary anger? BBC News April 11

Harrison, J., Bosse, D., \& Phillips, R. (2010). Managing for stakeholders, stakeholder utility functions and competitive advantage. Strategic Management Journal, 31, 58-74.

Harvey, D. (2005). A brief history of neoliberalism. Oxford: Oxford University Press.

Hendricks, F. (2008). The Mafeje affair: The University of Cape Town and apartheid. African Studies, 67(3), 423-451.

Henisz, W., Dorobantu, S., \& Nartey, L. (2014). Spinning gold: The financial and operational returns to external stakeholder engagement. Strategic Management Journal, 35(12), 1727-1748.

Hickel, J. (2015). Democracy as death: The moral order of anti-liberal politics in South Africa. Berkeley: University of California Press.

Hill, M. (1997). Whiteness: A critical reader. New York: New York University Press.

Hill Collins, P. (1990). Black feminist thought: Knowledge, consciousness and the politics of empowerment. London: Routledge.

Hill Collins, P. (2005). Black sexual politics: African Americans, gender, and the new racism. London: Routledge.

Hill Collins, P. (2013). On intellectual activism. Philadelphia: Temple University Press.

Hill Collins, P., \& Bilge, S. (2016). Intersectionality. Cambridge: Polity Press.

Hountondji, P. J. (1992). Recapturing. In V. Y. Mudimbe (Ed.), The surreptitious speech: Presence Africaine and the politics of otherness, 1947-1987 (pp. 238-248). Chicago: University of Chicago Press.

Ibarra-Colado, E. (2006). Organization studies and epistemic coloniality in Latin America: Thinking otherness from the margins. Organization, 13(4), 463-488.

Idemudia, U. (2009). Oil extraction and poverty reduction in the Niger Delta: A critical examination of partnership initiatives. Journal of Business Ethics, 90, 91-116.

International Labor Organization. (1964). Declaration concerning the Policy of Apartheid" of the Republic of South Africa. Retrieved from http://www.ilo.org/public/libdoc/ilo/1964/64B09_117_ engl.pdf. Accessed 3 Jan 2018.

Jack, G., \& Westwood, R. (2006). Postcolonialism and the politics of qualitative research in international business. Management International Review, 46, 481-501.

Kamanzi, B. (2015 March, 29). "Rhodes must fall"-Decolonisation symbolism-What is happening at UCT, South Africa?. The Post Colonialist April 9.

Kaplan, E. (2002). Many paths to partial truths: Archives, anthropology, and the power of representation. Archival Science, 2, 209-220.

Katz, R. (1993). The straight path: A story of healing and transformation in Fiji. Reading, MA: Addison-Wesley.

Khan, F., Munir, K., \& Wilmott, H. (2007). A dark side of institutional entrepreneurship: Soccer balls, child labour and postcolonial impoverishment. Organization Studies, 28, 1055-1077.

Khan, F., Westwood, R., \& Boje, D. (2010). "I feel like a foreign agent": NGOs and corporate social responsibility interventions into Third World child labour. Human Relations, 63, 1417-1438.
Laufer, W. S. (2003). Social accountability and corporate greenwashing. Journal of Business Ethics, 43, 253-261.

Lawson, T. (1997). Economics and reality. London: Routledge.

Lutz, D. W. (2009). African Ubuntu philosophy and global management. Journal of Business Ethics, 84, 313-328.

Lyotard, J. (1984). The postmodern condition: A report on knowledge. Minneapolis: University of Minnesota Press.

Maher, R. (2018). Squeezing psychological freedom in corporatecommunity engagement. Journal of Business Ethics. https://doi. org/10.1007/s10551-018-3898-y.

Mansbridge, J. J., \& Morris, A. (2001). Oppositional consciousness: The Subjective roots of social protest. Chicago: University of Chicago Press.

Masika, R. (2017). Mobile phones and entrepreneurial identity negotiation by urban female street traders in Uganda. Gender, Work \& Organization, 24, 610-627.

Medina, J. (2013). The epistemology of resistance: Gender and racial oppression, epistemic injustice, and resistant imaginations. Oxford: Oxford University Press.

Mignolo, W. D. (2007). The idea of Latin America. Oxford: Blackwell

Mignolo, W. D. (2009). Epistemic disobedience, independent thought and de-Colonial freedom. Theory, Culture \& Society, 26(7-8), $1-23$.

Miller, J. C. (1988). Way of death: Merchant capitalism and the Angolan slave trade, 1730-1830. Madison, WI: University of Wisconsin Press.

Mir, R. A., Mir, A., \& Upadhyaya, A. P. (2003). Toward a postcolonial reading of organizational control. In A. Prasad (Ed.), Postcolonial theory and organizational analysis: A critical engagement (pp. 48-73). New York: Palgrave Macmillan.

Misoczky, C. M. (2011). World visions in dispute in contemporary Latin America: Development x harmonic life. Organization, 18(3), 345-363.

Mitchell, R. K., Agle, B. R., \& Wood, D. J. (1997). Toward a theory of stakeholder identification and salience: Defining the principle of who and what really counts. Academy of Management Review, 22, 853-886.

Moodley, K. (1991). The continued impact of black consciousness in South Africa. Journal of Modern African Studies, 29(2), 237-251.

Moreton-Robinson, A. (2004). Whiteness, epistemology and indigenous representation. In A. Moreton-Robinson (Ed.), Whitening race: Essays in social and cultural criticism (pp. 75-88). Canberra: Aboriginal Studies Press.

Morris, A. D. (1984). The origins of the civil rights movement: Black communities organizing for change. New York: Free Press.

Morris, A. D. (2000). Reflections on social movement theory: Criticisms and proposals. Contemporary Sociology, 29(3), 445-454.

Morris, A. D. (2015). The scholar denied: W. E. B. Du Bois and the birth of modern sociology. Berkeley: University of California Press.

Muhr, S. L. (2011). Caught in the gendered machine: On the masculine and feminine in cyborg leadership. Gender, Work and Organization, 18(3), 337-357.

Munir, K., Ayaz, M., Levy, D. L., \& Willmott, H. (2018). The role of intermediaries in governance of global production networks: Restructuring work relations in Pakistan's apparel industry. Human Relations, 71(4), 560-583.

News24. (2015). Chumani Maxwele: No regrets for throwing faeces at Rhodes statue. Retrieved from https://www.news24.com/Archi ves/City-Press/Newsmaker-Chumani-Maxwele-No-regrets-forthrowing-faeces-at-Rhodes-statue-20150429. Accessed 3 Jan 2018.

Nussbaum, M. (2000). Women and human development: The capabilities approach. Cambridge: Cambridge University Press. 
Nussbaum, M., \& Sen, A. (Eds.). (1993). The quality of life. Oxford: Clarendon Press.

Onimode, B. (1978). Imperialism and multinational corporations: A case study of Nigeria. Journal of Black Studies, 9(2), 207-232.

Özkazanç-Pan, B. (2012). Publishing without betrayal: Critical scholarship meets mainstream journals. Scandinavian Journal of Management, 28, 209-217.

Pal, M. (2016). Organization at the margins: Subaltern resistance of Singur. Human Relations, 69, 419-438.

Pather, R. (2015). \#RhodesMustFall: No end in sight as students sit tight. The Daily Vox Mar 25.

Perez, A. M., Ahmed, N., \& London, L. (2012). Racial discrimination: Experiences of black medical school alumni at the University of Cape Town, 1945-1994. South African Medical Journal, 102(6), 574-577.

Perriton, L., \& Reynolds, M. (2004). Critical management education: From pedagogy of possibility to pedagogy of refusal? Management Learning, 35(1), 61-77.

Petersen, C. (2015). UCT refusing to hire black professors. Cape Times March 23.

Prasad, A., \& Mills, A. J. (2010). Critical management studies and business ethics: A synthesis and three research trajectories for the coming decade. Journal of Business Ethics, 94, 227-237.

Quijano, A. (2000). Coloniality of power and Eurocentrism in Latin America. International Sociology, 15(2), 215-232.

Ramoglou, S., \& Tsang, E. W. K. (2016). A realist perspective of entrepreneurship: Opportunities as propensities. Academy of Management Review, 41(3), 410-434.

Rawlinson, K. (2016). Cecil Rhodes statue to remain at Oxford after 'overwhelming support'. The Guardian January 29.

Rhodes, C. (1877). Confession of faith. Retrieved from https://mikem cclaughry.wordpress.com/the-reading-library/the-basement-justdox/just-dox-british-intelligence/cecil-john-rhodes-confession -of-faith-1877/. Accessed 3 Jan 2018.

Rhodes, C., \& Westwood, R. (2007). Letting knowledge go: Ethics and the representation of the other in the practice of international and cross-cultural management". In C. Carter, S. R. Clegg, M. Kornberger, S. Laske, \& M. Mesner (Eds.), Business ethics as practice: Representation, siscourse and performance (pp. 68-83). Cheltenham: Edward Elgar.

Rosenthal, C. (2018). Accounting for slavery: Masters and management. Boston: Harvard University Press.

Said, E. (1978). Orientalism. London: Penguin.

Sellers, J. (2004). Raising a ruckus. In T. Mertes (Ed.), A movement of movements, Is another world really possible? (pp. 202-215). London: Verso.

Sen, A. (1999). Development as freedom. Oxford: Oxford University Press.

Sen, A. (2005). Human rights and capabilities. Journal of Human Development, 6(2), 151-166.

Sen, A. (2007). Identity and violence: The illusion of destiny. London: Penguin.
Smith, L. T. (1999). Decolonizing methodologies: Research and indigenous peoples. London: Zed Books.

Spivak, G. C. (1988). Can the subaltern speak? In C. Nelson \& L. Grossberg (Eds.), Marxism and the interpretation of culture (pp. 271-313). Urbana: University of Illinois Press.

Spivak, G. C. (1990). The post-colonial critic. In S. Harasym (Ed.), The Post-colonial critic: Interviews, strategies, dialogues (pp. 67-74). New York: Routledge.

Spivak, G. C. (1999). A critique of postcolonial reason: Toward a critique of the vanishing present. Cambridge, MA: Harvard University Press.

Stiem, T. (2018). Statue wars: What should we do with troublesome monuments? The Guardian September 26.

Strauss, A., \& Corbin, J. (1998). Basics of qualitative research. London: Sage.

Suchman, M. (1995). Managing legitimacy: Strategic and institutional approaches. Academy of Management Review, 20(3), 571-610.

Suddaby, R. (2018). Objectivity and truth: The role of the essay in management scholarship. Journal of Management Studies, 56(2), 441-447.

Sveningsson, S., \& Alvesson, M. (2003). Managing managerial identities: Organizational fragmentation, discourse and identity struggle. Human Relations, 56(10), 1163-1193.

Tatli, A. (2012). On the power and poverty of critical (self) reflection in critical management studies. British Journal of Management, 23, 22-30.

The Oppidan Press. (not dated). Decolonising the South African university. Retrieved from https://oppidanpress.atavist.com/decol onisation. Accessed 3 January 2018.

Thornton, J. (1998). Africa and Africans in the making of the Atlantic world, 1400-1800. Cambridge: Cambridge University Press.

Tobias, P. V. (1980). Apartheid and medical education: The training of black doctors in South Africa. Journal of the National Medical Association, 72, 395-410.

Udofia, O. E. (1984). Imperialism in Africa: A case of multinational corporations. Journal of Black Studies, 14(3), 353-368.

Ulus, E. (2018). White fantasy, white betrayals: On neoliberal 'feminism' in the US presidential election process. Ephemera, 18(1), $163-181$.

Van Der Merwe, M. (2015). \#FeesMustFall: No end in sight. Daily Maverick October 28.

Varman, R., \& Al-Amoudi, I. (2016). Accumulation through derealisation: How corporate violence remains unchecked. Human Relations, 69(10), 1909-1935.

Wesseling, H. L. (1996). Divide and rule: The partition of Africa, 1880-1914. Westport, CT: Praeger Publishers.

Publisher's Note Springer Nature remains neutral with regard to jurisdictional claims in published maps and institutional affiliations. 